\title{
Türkiye'de Merkez Sağ Parti İktidarlarının Toplumsal Hareketlere Yaklaşımı*
}

The Approach of Centre-Right Party Powers to Social Movements in Turkey

\section{Canan KATILMIŞa}

${ }^{a}$ Doktora Öğrencisi, İnönü Üniversitesi İiBF, Malatya/Türkiye, canan.katilmis@gmail.com, ORCiD 0000-0001-5978-2674

\section{ÖZ}

Bu çalışmada, Türkiye'de merkez sağ parti iktidarlarının toplumsal hareketlere yaklaşımının ortaya konması amaçlanmıştır. BU amaçla sürdürülen çalışmada toplumsal hareketler, bir siyasal katılım aracı olarak ele alınmıştır. Merkez sağ parti iktidarları ve toplumsal hareketlerin temel nitelikleri, bilgi derleme araçları yoluyla edinilen bilgiler üzerinden sürdürülmüştür. Merkez sağ parti iktidarlarının iktidar olduğu dönemde meydana gelen toplumsal hareketleri yorumlama biçimleri ve yaklaşımları ise, internet kaynakları ve arşiv araştırması yoluyla değerlendirilmeye çalışılmıştır. Araştırmada öncelikle, Türk siyasetinde ağırlıklı bir yere sahip olan merkez sağın tarihi, özellikleri, geçirdiği dönüşüm ve ideolojisinden bahsedilmiştir. Sonrasında ise, toplumsal hareketler kavramsal olarak ele alınmış, Türkiye'de toplumsal hareketler ve özellikleri ifade edilmiştir. Çalışmanın son bölümünde, Türkiye'de merkez sağ parti iktidarlarının toplumsal hareketleri yorumlama biçimi ve yaklaşımı değerlendirilmiştir. $\mathrm{Bu}$ değerlendirme ile demokrasiye katkı sağlayan toplumsal hareketlerin, Türkiye'de demokrasiyi kesintiye uğratacak askeri müdahalelerin nedeni ya da sonucu olarak yorumlandığı sonucuna varılmıştır. Ayrıca toplumsal hareketeler, iktidarı anti-demokratik yöntemler ile kaybedeceği endişesi taşıyan merkez sağ parti iktidarları tarafından, sisteme karşı bir başkaldırı olarak görülmüştür. Bu nedenle toplumsal hareketler, Türkiye'de demokrasiyi besleyen bir unsur olarak varlık göstermemiştir.

Anahtar Kelimeler: Merkez Sağ, Toplumsal Hareketler, Türkiye.

\begin{abstract}
In this study, it is aimed to show the approach of the centre-right party powers to social movements in Turkey. In the work carried out for this purpose, social movements are considered as a means of political participation. The main characteristics of the centre-right party powers and social movements were maintained through the knowledge acquired through the means of information compilation. The methods and approaches of interpreting the social movements that occurred during the period of power of the centre-right party have been tried to be evaluated through internet resources and archival research. Firstly, the history, characteristics, transformation, and ideology of the centre-right, which has a predominant place in Turkish politics, are mentioned in the research. Then, social movements are conceptually discussed and social movements and their characteristics have been expressed in Turkey. In the last part of the study, the way and approach of centre-right party governments in Turkey to interpret social movements is evaluated. It is concluded that social movements contributing to democracy are interpreted as the cause or result of military interventions that would disrupt democracy in Turkey. Furthermore, social movements have been seen as a rebellion against the system by the centre-right party powers, which are worried about that they will lose power through anti-democratic methods. For this reason, social movements did not exist as an element that nurtured democracy in Turkey.
\end{abstract}

Keywords: Center-Right, Social Movements, Turkey.

\footnotetext{
* Bu makalede bilimsel araştırma ve yayın etiği ilkelerine uyulmuştur. / In this article, the principles of scientific research and publication ethics were followed.
} 


\section{GİRİ̧}

Tarihsel olarak, binlerce yıldan beri dünyanın farklı yerlerinde bir çeşit ayaklanma türü olarak meydana gelen toplumsal hareketler, 18. yüzyılın sonlarına doğru kendine özgü özellikleri ile diğer siyasal katılım biçimlerinden ayrılmıştır. Toplumsal hareketler; cinsiyet grupları, meslek grupları, işçiler, öğrenciler, entelektüel kesim gibi toplumun farklı kesimlerinin siyasi, sosyal ve ekonomik sebeplerden kaynaklı bir veya birden fazla şikâyet etrafında bir araya gelmeleriyle oluşan hareketlerdir.

Ufak tefek örgütlenmeler olarak meydana gelen toplumsal hareketler, zamanla daha organize, daha çok desteklenen, toplumsal hareketlerin işleyişinde uzmanlaşmış kişilerden oluşan, daha çok finanse edilen hareketler haline gelmiştir. Bu nedenle siyasi olana dikkat çekmek isteyen toplumsal hareketler, bir siyasi katılım aracı olarak siyasi alana katkıda bulunmuştur. Ancak bazen toplumsal hareketler siyasi baskının olduğu bir ortamda siyasi iktidarı sınırlandırmakla kalmak istememiştir. Her iktidarın iktidar alanını genişletme isteği ve eğilimi söz konusu olduğu gibi, toplumsal hareketlerin de devlete karşı kuvvetler olarak iktidarı etkilemek, sınırlandırmak ve değiştirmek isteği söz konusu olmuştur. Bu nedenledir ki, Türkiye'de siyasi alana katkı sağlaması beklenen toplumsal hareketler, iktidarını kaybetme korkusu yaşayan sağ parti iktidarları tarafından çoğu zaman bastırılmış ve yok sayılmıştır. Bazen gerçekten bu tehdit söz konusu olduğu için bazen de böyle bir tehdidin varlığı Türk siyasal hayatı içinde çokça tekrar ettiği için, toplumsal hareketler Türkiye'de siyasi katılımı arttıran, siyasi alanı genişleten, demokrasiyi besleyen hareketler olarak yer bulamamıştır.

Bu çalışmada, Türkiye'de merkez sağ parti iktidarlarının, iktidarları döneminde meydana gelen toplumsal hareketleri yorumlama biçimleri ve toplumsal hareketlere yaklaşımları değerlendirilmeye çalışılacaktır. Aynı zamanda toplumsal hareketlerin, Türk siyasetinde önemli bir ağırlığa sahip olan merkez sağ parti iktidarları tarafından nasıl yorumlandığının değerlendirilmesi, Türkiye'de toplumsal hareketlerin demokrasiye katkısını değerlendirmek açısından da faydalı olacaktır. Türkiye'de çok partili hayata geçiş ile başlayan merkez sağın tarihi, merkez sağın özelliklerini ve toplumsal hareketleri yorumlama biçimini ortaya koymak için ayrıca önem arz etmektedir. Bu nedenle, Türkiye'de merkez sağın tarihi ve geçirdiği dönüşüm üzerinden parti iktidarlarının toplumsal hareketlere karşı tutumları ve bu tutumlarının haklı haksız gerekçeleri üzerinde değerlendirilme yapılacaktır. Çalışmada, nitel araştırma yöntemi kullanılacak olup, değerlendirmeler merkez sağ parti iktidarları ve Türkiye'de meydana gelen toplumsal hareketlere ilişkin açık kaynak verileri, basılı metinler, haber ve internet kaynaklarından faydalanılarak yapılacaktır. Ayrıca Türkiye'de merkez sağın tarihi, toplumsal hareketlerin ve merkez sağ parti iktidarlarının özellikleri bilgi derleme araçları yolu ile ortaya konulacaktır.

\section{TÜRKIYYEDE MERKEZ SAĞIN TARIHİ}

Türkiye'de merkez sağ siyaset, çok partili hayata geçiş ile kurulan Demokrat Parti (DP) ile başlamıştır. DP'den sonra kurulan ve Türk siyasal hayatı literatüründe merkez-sağ olarak tanımlanan diğer başlıca siyasi partiler şunlardır: Adalet Partisi (AP), Anavatan Partisi (ANAP), Doğru Yol Partisi (DYP), Adalet ve Kalkınma Partisi (AK Parti). Merkez să̆ partilerin, genellikle kendilerini milliyetçilik, muhafazakârlık ve dini söylemler üzerinden tanımlarken, aşırı muhafazakâr, dini ve milliyetçi söylemlerden uzak durdukları görülmektedir. Tüm bu bilgiler ışığında merkez să̆ partilerin, koyu milliyetçiliği ve dindar muhafazakârlığı temsil eden diğer sağ partilerden nasıl ve ne kadar ayrıldığını anlamak için sağın tarihine, kendini merkez olarak tanımlamasına, genel özelliklerine ve dönüşümüne bakmakta fayda vardır.

\subsection{Türkiye’de Merkez Sağ Siyasetin Oluşumu}

Çok partili hayata geçiş sürecinde yaşanan siyasi gelişmeler neticesinde belirginleşen, DP ve Cumhuriyet Halk Partisi (CHP) tarafından temsil edilen değerler, günümüze kadar Türk siyasetine yön vermiştir. Tüm toplumsal ve siyasi hareketlerin de bu iki merkezin temsil ettiği değerlerden beslendiği görülmektedir. Bunlardan biri Cumhuriyet'in kurucu partisi CHP, diğeri ise CHP içinden ve CHP'de bir reformun gerekliliği üzerinden yola çıkan milletvekilleri tarafından kurulan DP'dir. Türkiye'de merkez sağ siyasetin serüveni de kendinden sonra gelen birçok partinin referans aldığı DP'nin kurulması ile başlamıştır (Zürcher, 2013:310).

CHP'nin 27 yıllık iktidarı süresince birkaç kez çok partili hayata geçiş denemesi yapılmışsa da, İkinci Dünya Savaşı'ndan sonra oluşan demokratikleşme çabalarına kadar, çok partili hayata geçiş ile ilgili kararlı bir girişimde bulunulmamıştır. İkinci Dünya Savaşı'ndan sonra demokrasilerin zaferi ve Türkiye'nin Sovyet tehdidi karşısında Batı ile yakınlaşma ihtiyacı, reform hareketlerini hızlandırmıştır (Özbudun, 2010: 16). Bu nedenledir ki İsmet İnönü, 1945 ’te meclisin açılışı dolayısıyla yaptığı konuşmada, siyasal sistemde önemli bir değişikliğe ihtiyaç olduğunu ve bu değişiklikleri dünyada meydana gelen değişiklikler ile aynı çizgiye getirmeye hazır olduğunu belirtmiştir. Ayrıca, Türk siyasal sisteminde başlıca eksikliğin bir muhalefet partisi eksikliği olduğunu söyleyerek çok partili hayatın sinyallerini vermiştir (Ahmad, 1999: 125). Sadece dış etkenler değil, aynı zamanda içerde yaşanan birtakım gelişmeler de çok partili hayata geçiş sürecini hızlandırmıştır. Parti içerisinde çok partili hayata geçiş sürecine kadar ara sıra muhalif söylemler olmuştur. Ancak, ilk defa Ocak 1945'te Meclis'e sunulan Çiftçiyi Topraklandırma Kanunu üzerine yapılan tartışmalar, hükümetin şiddetle eleştirilmesine neden olmuştur (Çufalı, 2005: 408). Bu yasaya muhalefette bulunanlar, Meclis'te bulunan toprak sahibi milletvekilleridir. Yine bu milletvekillerinin sözcüsü Aydın Milletvekili, büyük toprak sahibi olan Adnan Menderes’tir. Yasa, milletvekillerinin sert tepkisine rağmen kabul edilmiştir (Zürcher, 2013: 309). Yasayı eleştirenler, hükümete biri anayasal diğeri ekonomik olmak üzere iki nedenden ötürü tepki vermiştir. Toprak reformu ile anayasanın garanti altına aldığı özel mülkiyet ihlal edildiği gibi, yasanın aynı zamanda üretimde de azalmaya yol açacağı gerekçesiyle oluşan muhalefet, genişleyerek devam etmiştir (Ahmad, 1999: 126).

Bu süreçte geçmişte (1937-39) başbakanlık yapan, bankacı ve iktisatçı Mahmut Celal Bayar; hukukçu, toprak zengini Adnan Menderes; deneyimli bürokrat Refik Koraltan ile ülkemizin entelektüel hayatında ön siralarda yer alan tarih profesörü 
Fuat Köprülü, ülkenin demokratikleşmesi adına ne yapılabilir sorusuna cevaplar aramış ve nihayet bir takrir verilmesi hususunda oydaşmaya varmışlardır. Dörtlü Takrir olarak adlandırılan önerge, CHP'de firtınalar koparmış ve nitekim Türkiye'de merkez sağ siyasetin miladı sayılan DP'nin kuruluş yolunu açmıştır. Milli Şef İnönü’nün icazetinin alınmasından sonra vücut bulan DP, 1946-50 yılları arasındaki muhalefet ve 1950-60 yılları arasındaki iktidar tecrübesiyle Türk siyasal hayatına damgasını vurmuştur (Özdemir, 2012: 189-190).

DP iktidarı Türkiye’ye demokrasinin iki temel ilkesini kazandırmıştır. Bunlardan ilki sadece demokratik yönetimlerde var olan muhalefettir. Bu rejim, DP’nin çabasıyla yerleşmiştir. Bir diğeri ise, dört yılda bir seçim yapılmasını, oyların gizli verilip açık sayılmasını, seçime dileyen partilerin katılmasını sağlayan genel oy ilkesidir. Seçimlerin yargı denetimine tabi tutulacak olması ise diğer önemli bir ilkedir (Kahraman, 2007: 9). DP, tek parti iktidarı altında demokrasi kavramıyla tanışık olmayan bir toplumu demokrasi ve liberalizm ile tanıştıracağına dair bir görev ile yola çıkmıştır. Geniş kitlelerin inanç, hayat ve değer tarzının siyasi temsili olarak kendini göstermiştir. Bu nedenle, merkez sağ çatısı altında ortaya çıkan tüm söylemlerin ve pratiklerin arkasında, DP iktidarının kısa tarihi yer almaktadır (Mert, 2007: 20).

\subsection{DP'den Ak Parti'ye Merkez Să̆'ın Tarihi}

DP, çok güçlü bir destek alarak 14 Mayıs 1950'de iktidara gelmiştir. İktidara gelen DP'nin politikalarında, daha kapsamlı bir siyasal dönüşüm beklenmiştir. DP, İktidara geldiğinde özellikle özel teşebbüs, özgürlük ve anti-komünizm gibi konular üzerinde durmuştur. (Kahraman, 2010: 238). DP'nin kurucularından Menderes vekillik görevinin 16 yılını CHP'de yapmış biri olarak, siyasi kültürü ile geçmişten getirdiği pek çok bilgi ve tecrübeye sahiptir. İnönü’nün silah arkadaşı olan Bayar ise, Başbakanlık ve Atatürk'ün iktisat vekilliği gibi birçok önemli görevde bulunmuştur. Partinin diğer en önemli kurucularından Tarih Profesörü olan Köprülü ve Türkiye Büyük Millet Meclisi (TBMM) mebuslarından Koraltan da önemli siyasi görevlerde bulunmuştur ( 32 . Gün Arşivi, 2017). CHP kültürünün içinden çıkıp gelen DP, çok ciddi değişiklikler yapmasa dahi tek parti döneminde baskı altında kalmış bütün gruplara kucak açmıştır. Çiftçiyi Topraklandırma Kanunu ile küçük köylüyü, Dörtlü Takrir ile aydınları, bütçeyi eleştirerek kentli ve taşralı esnafları, grev hakkını savunarak işçileri yanına çekerek kollektif bir parti kimliği inşa etmiştir (Kahraman, 2010: 242).

DP'nin ilk üç yılında tarım ürünleri bollaşmış ve çiftçinin geliri artmıştır; ancak DP'nin serbest ve devlet baskısından uzak tüm liberal hedeflerine rağmen, bu dönemde yatırımların neredeyse \%50'sine kadarını devlet yapmak zorunda kalmıştır (Zürcher, 2004: 327). Büyük bir destek alarak iktidara gelen DP, zamanla aldığı kararlar ve uyguladığı politikalar ile eski desteğini kaybetmiştir. DP'nin basına sınırlamaları, radyonun kamu menfaatinden uzaklaşarak sadece DP'nin propaganda aracı haline gelmesi, 6-7 Eylül Olayları, ispat hakkı, Hürriyet Partisi, 29 Kasım 1955 DP grup toplantısı vb. gelişmeler DP'ye muhalefeti arttırmıştır (Gökmen, 2012: 369). DP'nin Türk siyasetine en önemli katkısı siyasete verdiği yöndür. DP siyaseti ile ilk defa seçimler toplumun rızasına müracaat etmek zorundadır. Bu tek yönlü bir müracaatı ve onaylanmayı içermemektedir. Toplumun rızasına müracaat, aynı zamanda sistemi topluma onaylatmak demektir. Bugün merkez sağ olarak adlandırılan DP'nin söylemleri ile siyasal hayata katılım sağlayan geniş kalabalıklar aynı zamanda, Cumhuriyet rejiminin teyit edilmesine de önemli derecede katkı sağlamıştır. Bu nedenle, tüm merkez sağ söylemler kendilerini DP mirasına dayandırmaya özen göstermiştir (Mert, 2007: 10). Tarih 27 Mayıs 1960'1 gösterdiğinde, ilk defa halk tarafından seçilmiş bir hükümet olan DP hükümeti, askeri müdahale ile görevden alınarak yargılanmıştır. Mahkeme kurularak yargılanan Menderes, Türk siyasi hayatında idam edilen ilk ve tek başbakan olarak tarihe geçmiştir. Ayrıca Milli Birlik Komitesi, Maliye Bakanı Hasan Polatkan'ın ve Dış İşleri Bakanı Fatih Rüştü Zorlu'nun da idam cezasını onaylamıştır (Heper, 2011:195).

DP kapatıldıktan sonra Milli Birlik Komitesi siyasi partilerin “demokrat” adını kullanmasını yasaklamıştır. Bu nedenle DP'nin mirasçısı olan AP, Adalet Partisi adı ile kurulmuştur. DP'den sonra kurulan AP'nin içinde birçok eski DP'li politikacı yer almaktadır. AP, siyasi yelpazenin sağ kanadındaki boşluğu dolduracak başlıca parti olmuştur. Parti politikaları ve programı incelendiğinde, AP'nin kendisini merkez sağ ve liberal görüşlü bir parti olarak tanımladığı görülmektedir. AP, 1961-1980 yılları arasında varlığını sürdürmüştür. Halkın dini isteklerine karşı hoşgörülü davranan AP, DP gibi serbest ticareti ve girişimi desteklemiş, aynı zamanda kırsal kesimin ihtiyaçlarına karşı duyarlı davranmıştır (acikerisim.tbmm.gov.tr, 2019). AP, 1961 Anayasası'nın halk oylaması ile onaylanmasına karşı çıkmış, 1961 genel seçimlerde orduyu eleştirmiş, eski Demokratlar için sık sık af meselesini gündeme getirmiştir (Heper, 2011: 196). 1965 ve 1971 yılları arasında tek başına hükümet kurmuştur. 1970'li yıllara gelindiğinde ise koalisyonlarda ülke yönetiminde söz sahibi olmuştur. 1980 yılında diğer siyasi partilerle birlikte kapatılmıştır. İdamların ardından oluşan toplumsal tepkiyi en doğru şekilde değerlendirmeyi başaran AP, DP seçmen tabanının büyük bir kısmını yanına çekmeyi başarmıştır (Adalet Partisi, 2019).

AP, temelde laik bir partidir. Muhafazakâr ve liberal çevrelerin merkezine oturabilmiştir. Toplumsal ilişkilerde dinsel öge ve yapıları korumak ile birlikte, Bülent Ecevit'ten önceki dönemde CHP'nin aydın-bürokrat seçkinlerinin ve lider kadrosunun temsil ettiği devlete karşı, dengeleyici bir güç olarak hareket etmiştir. 1960'lardan sonra AP içerisinde anlaşmazlıklar baş göstermeye başlamıştır. 1970'lere gelindiğinde ise, bu anlaşmazlıklar bölünmeyle son bulmuştur. İslamcı ve liberal kanat partiden kopmuştur (Heper, 2011:196). AP'den ayrılan isimlerden, iş dünyasının ve kırsal kesimin çıkarlarını temsil eden Ferruh Bozbeyli ve arkadaşları ise ayrılarak Demokratik Parti'yi kurmuştur. 1970’lerde artan sağ-sol çatışmaları bir süre sonra sağ ve sol gruplar arasında silahlı çatışmaya dönüşmüştür. Hükümetin ülkeyi iyi yönetemediği gerekçesi ile 12 Mart 1971 'de bir muhtıra ile Demirel hükümeti istifaya zorlanmıştır. 12 Eylül 1980 darbesinin ardından ise AP, diğer siyasi partiler ile birlikte kapatılmıştır (Adalet Partisi, 2019).

1982 yılında çok partili sisteme yeniden geçildikten sonra Büyük Türkiye Partisi (BTP) kurulmuştur. Ancak MGK, AP'den farklı olmadığı gerekçesiyle BTP'yi kapatmıştır. 1983 yılında, BTP’nin kapatılmasından sonra kurulan DYP ile merkez sağda 
demokrasi vurgusu yeniden gündeme gelmiştir. Demirel'in partisi DYP siyasi söylemleri ile 12 Eylül 1980 Askeri Darbesi'ne karşı demokrasi üzerinde durmuştur (Mert, 2007: 56). DYP'nin başından beri amacı AP'nin kapatılmasıyla merkez sağda oluşan boşluğu doldurmaktır. DYP Genel Başkanı Hüsamettin Cindoruk'un, demokratik olmayan hükümlerin yürürlükten kaldırılmasına yönelik geliştirdiği sivilleşme projesi, Demirel döneminde sürdürülmüştür. Demirel'in Parti başkanlığını Cindoruk'tan devralması ile DYP, demokratikleşme adına politikalar üretmeye başlamıştır. 1982 Anayasası'nda yer alan ve siyasi faaliyetleri kısıtlamaya yönelik maddeleri kaldırmak isteyen DP, vatandaşın refahına ve sosyal devlet politikalarına eğilmiştir. DYP'nin nihai amacı, ulusal iradenin üstünlüğünün engellenmeden kullanılmasını sağlamaktır (acikerisim.tbmm.gov.tr, 2019). DYP'nin merkez sağda ikinci kez yükselen demokrasi vurgusu 28 Şubat 1997'yi takip eden dönemde, DYP'nin Refah Partisi (RP) ile oluşturduğu koalisyon hükümetine karşı gerçekleşen müdahale ile olmuştur. Bu dönemde DYP lideri olan Tansu Çiller, merkezdeki muhalifi Mesut Yılmaz'1 askerlerle iş birliği yaparak merkez sağın demokrasi geleneğini zedelemekle suçlamıştır (Heper, 2011: 204). 1997'lere gelindiğinde DYP, demokrasi vurgusu ile yürüttüğü siyasetin en son aşamasında ilkini DP'nin ilan ettiği demokrasi programının ikincisini yayımlamıştır. DYP, DP'nin demokratikleşme sürecinde attığı adımın radikal bir adım olduğunu ve DP demokrasi geleneğini sürdürdüğünü dile getirmiştir. DP iktidarı döneminde, “jandarma dipçiği ve tahsildar zulmünün yerini güleryüzlü bir devlete bıraktığını; ancak zamanla milli iradenin hükmünün geçersiz kılındığını bu nedenle milli iradeyi egemen kılacak olan yeni bir demokrasi programının gerektiğini’” dile getirmiştir. DYP'nin “'̇kinci Demokrasi Programı’ ile amaç, milletin gerçek temsilcilerini iktidar etmektir. Bu koşullar altında iktidara gelen devletin, güleryüzlü ve milletin devleti olabileceği belirtilmiştir (Mert, 2007: 57).

Türkiye'de bir yapılandırma süreci olarak başlayan ve yeni bir devlet formuna geçiş için atılan en önemli adımlardan bir diğeri ise, 24 Ocak 1980 kararlarıdır. 12 Eylül 1980 Askeri Darbesi ve darbenin ürünü olan 1982 Anayasası ile devam eden bu süreç, 1983 yılında seçimler ve ANAP'ın tek başına iktidarı ile devam etmiştir. Türk siyasal yaşamı açısından önemli olan bu süreç merkez sağın hegemonya mücadelesi verdiği son derece önemli bir dönemdir (Erdoğan, 2008: 86). Özal, Cumhuriyet'in inşa ettiği batıl1-laik-şehirli statükodan şikâyet etmek yerine bu tanımı dönüştürme yoluna gitmiştir (Mert, 2011: 58). Özal'ın amacı, girişimci faaliyetlerin önündeki engelleri kaldırarak piyasa ekonomisine katkı sağlamak ve ekonomik alandaki istikrarı siyasi alanda inşa etmektir. Özal, siyasi katılım ve adalet gibi alanlarda pek özenli davranmamıştır. Ancak, halkın devlete hizmet için değil, devletin halka hizmet için var olması gerektiğini sık sık dile getirmiştir. 1983 sonrası dönemde rejimin sorunsuzca sivilleştirilmesinde önemli bir rol oynamıştır (Heper, 2011: 207).

ANAP'tan sonra merkez sağ tarihinde bazı açılardan kırılmayı temsil eden AK Parti ise, 14 Ağustos 2001 'de kurulmuştur. Fazilet Partisi'nden önceki Refah Partisi ve Fazilet Partisi'nin devamı olduğuna dair bir algı ile siyaset sahnesine çıkan AK Parti, bu algıyı değiştirecek bir söylem ile iç ve dış kamuoyuna kendisini muhafazakâr-demokrat bir kimlik ile tanıtmıştır. Diğer merkez sağ partiler ile benzer bir klasik söylemi devam ettirerek kendisini " milletin gerçek temsilcisi'" ilan etmiştir ( Mert, 2007: 104). Dış basın AK Parti’ye, 1lımlı İslamcı bir kimlik ile yer verirken ülke içindekiler ise AK Parti’nin laiklik ilkesine bağlı kalıp kalmayacağını sorgulamıştır. Bu eleştiriler, Türk demokrasi tarihini ve siyasal gelişmeleri yakından izleyenler için yeni bir muhalif söylem olarak algılanmamıştır. DP, AP ve ANAP'ta Cumhuriyet'in laiklik ilkesine karşı olmak ve irticaya prim vermek gibi eleştirilere maruz kalmıştır. AK Parti'nin tecrübesi, siyasi ve ekonomik politikaları, iktidar süresinde sergilediği Avrupa Birliği (AB) merkezli reformist tutumu, iç politikada demokrasiyi sıklıkla gündeme getirdiği demokrasi vurgusu, özgürlükleri genişletici anayasal adımları, siyasi refleksleri, kriz yönetimi ve dış politikada sergilediği tutum ile dâhili ve harici mekânlarda tartışılmaya başlanmıştır (Akgün, 2006: 25).

\subsection{Merkez Sağ Siyasi Partilerin Genel Özelliği}

İçinde geliştiği siyasi kültüre sırtını dayayan sağın düşünce ve hareket bakımından en önemli parçalarından birisi, merkez sağdır. Siyasette merkez, iki uç siyasi düşünce arasındaki merkezi siyasi düşünceyi ve hareketi ifade eder. Gerek sağ gerek sol düşünceyi ifade eden merkez, aşırı sağ ve sol uç siyaset arasında bir yerde konumlanmaktadır. İlk kullanımı ile merkez, Batı'da genelde sosyalist, faşist ve komünist politikalara karşı olmak anlamında kullanılmıştır. Bu anlamıyla merkez sağ, popüler ve kitlesel partilerce temsil edilen sağın ya da solun içinde yer alan; ancak aşırı sağ ve sol ideolojilerden uzak siyasi düşünceleri temsil etmiştir. Kitle partilerince temsil edilen merkez sağ, geniş siyasi düşüncelere ve ideolojilere dayandığından popülisttir (Giovanni, 1996). Türkiye'de merkez sağ benzer özellikler ile gelişme göstermiştir. DP, seçkin bir tabaka tarafından yıllarca halkın çıkarlarının bastırıldığını ve engellediğini varsayan, devlet organlarının bu seçkin tabakanın etkisinden çıkarılıp halkın yararı ve toplumun gelişmesi için kullanılması gerektiğini söyleyen siyasî bir felsefe üzerinden siyaset üretmiştir. 1946’nın ruhu ve 1950'lerde DP'nin öncülügünde ve AP'nin 1960'larda ve 1970'lerde temsil ettiği himaye ve popülizm siyaseti, 1980'de askeri müdahaleye kadar Türk siyasetinde baskın güç olmaya devam etmiştir (Sunar, 2004: 129). Bununla beraber, DP'nin iktidar olmasıyla ortaya çıkan sağ siyaset söylemi, Cumhuriyet rejiminin getirdiği değişikliklerin toplumda yarattığı tepkiler ile liberal ekonomik politikaların birleşme noktasından meydana gelmiştir. Türkiye'de çok partili hayat, demokrasiye geçiş için başlangıç olduğu gibi merkez sağ için de başlangıçtır. Bu nedenle, Türkiye'de merkez sağ, sürekli demokrasi vurgusu yapmıştır. Merkez sağı temsil eden tüm partiler çoğunluktan aldıkları "milli iradeyi", tüm milletin adına kullanmıştır. Merkez sağ siyasetin en önemli kalkış noktası da budur. Bu nedenle milli iradeyi ifade eden sivil siyaseti özellikle vurgulamıştır ( Mert, 2007: 97). Türkiye'de merkez sağ partilerin özellikle demokrasi vurgusu, DP geleneğine bir göndermedir. DP başından beri devletin partisine, katı laikliğe, batıcılığa ve topluma yabancılaşmış bir kesimin hâkimiyetine karşıdır. Bu nedenle kendini, 'milletin partisi’ yani seçkinci karşıtlığ , dinsel muhafazakârlık ve yerlilik temaları üzerinden tanımlamıştır (Mert, 2007: 52). Ancak, Türkiye'de merkez sağ, dine dayalı bir devlet modelini desteklememiştir. Türkiye Cumhuriyeti'nin kurucu düşüncesi olan laiklik, baskın bir karakter olarak Türkiye'de tüm siyasete yön vermiştir. Bu nedenle, merkez sağ partiler, laiklik meselesinin kırılganlığının farkındadır ve rejimin sınırları içinde kalmaya özen göstererek pasif bir laiklik anlayışı benimsemiştir. Laikliğe 
bağlı kalındığını göstermekle birlikte, din üzerindeki baskıları azaltmaya çalışmış ve dini kitlelerle iletişim kurmaya yönelik bir dil olarak kullanmıştır. Dinin kamusal alandaki varlığının göreceli olarak özgürleştirdiğini gösterecek adımlar atmıştır (Mardin, 2018: 67-164). Türkiye'de siyasi partiler orta sınıfların olmadığı bir ortamda kurulmuştur. Türkiye'nin siyasal açılımlarının meydana geldiği bu süreçte, devleti oluşturan seçkinler farklı sosyo-ekonomik kesimler ile inatçı ve etkin yerel zümrelerin talepleriyle de karşı karşıya gelmemiştir. Bu nedenle farklı taleplere ve beklentilere karşı tedirgin olmuş, farklı hayat görüşlerine karşı hoşgörülü olamamıştır. Günümüze kadar, DP'yi ve merkez sağ parti iktidarlarını ayakta tutan şey, seçkinlerin iktidarı elinde tutma çabalarına karşı göstermiş olduğu dirençtir. Bu nedenledir ki DP, iktidarda olduğu dönemde benimsediği politikaları uygulayabilmek için bürokratik seçkinlere muhtaç olduğu halde eleştirilerini çoğu zaman seçkinlere ve onların temsil ettiği dünya görüşüne getirmiştir (Heper,2012: 168).

Türkiye'de merkez sağ siyasetin özelliklerini şekillendiren bir diğer unsur darbelerdir. Türk siyasetinde ordusuz bir siyaseti düşünmek mümkün olmamıştır. Türkiye Cumhuriyet'inin çok partili hayata geçişle başlayan demokratikleşme sürecine darbeler dönemi eşlik etmiştir. Türkiye'de görünürdeki demokratik kurumlara rağmen baskın irade, gerçekte egemen olan askerin iradesi olmuştur. Türkiye Cumhuriyet döneminden günümüze kadar zaman zaman milli iradenin rafa kaldırıldığı, parlamento ve hükümete belirli temel politikaların dayatıldı̆̆ verme gayreti içinde olduğu dönemleri yaşamıştır. Bu durumlarda iktidar darbe ve müdahaleden sonra sivil yönetime devredilse bile, yönetimi devralan sivil yönetim ordunun sahne arkasında etkin bir güç olarak varlığından haberdar olmuştur (Erdoğan, 2005:741).

Türkiye'de merkez sağı bağlı bulunduğu bu siyasal rejim içinde değerlendirdiğimizde, evrensel ve yerel değerleri bir arada tutarak, kültürel farklılıkların oluşturduğu sorunları en aza indirmek için bir denge kurmaya gayret ettiği görülmektedir. Türkiye de merkez să̆ ideoloji bir şeyin devamı olarak ortaya çıkmamıştır. Sağın içinde oluşmuş ve gelişmiştir. Batı'daki gibi sağın ve solun arasında yer almayan merkez sağın ideolojisi, kendine özgüdür. Zamanla kendi değerlerini oluşturan eklektik bir yapıdır. En temel özelliği ılımlılıkla ifade edilen orta yoldur. Merkez sağın içinden çıkan DP'liler, CHP'den bir kopuşu, bir fikir ayrılı̆̆ını ifade etmiştir. Bunun bir yansıması olarak merkez sağ devrimci yöntemler değil, reformcu yöntemler geliştirmiştir (Erken, 2016: 198). Özellikle, İkinci Dünya Savaşı'ndan sonra liberal ekonomik politikaları toplumun zihniyeti, değerleri ve bakış açısıyla birleştirmeyi başarmıştır. Bu bağlamda, Türkiye'deki merkez sağ partilerin evrensel değerleri takip ederek yerel değerlerle bütünleşmeye ve uyum içinde hareket etmeye gayret eden dinamik bir yapıya sahip olduğu görülmektedir. Yine Türkiye'de merkez sağ, aşırı uçlara kapalıdır. Bu nedenledir ki, uç ideoloji ve fikirlerden uzak olduğuna dair söylemlere sıklıkla yer vermiştir. Bu şekilde bütün farklı fikirleri kendi bünyesine dâhil etmeye çalışmıştır. (Enerem, 2018: 72).

Türkiye'de merkez sağın, demokrasi hususundaki davranışları değerlendirildiğinde, devlet seçkinlerinin ve ordunun yönetimdeki etkilerini zamanla zayıflatarak sivil siyasetin ortaya çıkmasında ve gelişmesinde katkısı olduğu görülmektedir (Heper, 2011:219). Ancak, Türkiye'de merkez sağın eşitlikle ve demokratik sistemin özelliklerine yönelik meselelerden ziyade demokrasiyi daha çok prosedürel olarak milli iradeyi kazanmak için bir mücadele unsuru olarak gördüğü anlaşılmaktadır. Merkez sağ zamanla, demokrasiyi çoğunluğun beklentilerini temsil etmeye, seçim kazanmaya, kitleleri yakalamaya yardımcı olduğu için önemsemiştir. Kısacası sivil kavramının merkez sağ siyaset içerisindeki macerası, demokrasi kavramının macerasına benzemektedir. Türkiye'de demokrasi kavramı merkez sağ için "milletin gerçek temsilcisi”" olarak kabul edildiği gibi, sivil siyaset de büyük ölçüde "bizden birine”, dönüşmüştür ( Mert, 2007: 61).

\subsection{Türkiye'de Merkez Sağ Siyasetin Dönüşümü}

Türkiye Cumhuriyeti kurulurken askeri ve bürokratik elitler tarafindan kurulmuş, bürokratik kadrolar tarafindan yönetilmiş ve bürokrasi ile uyumlu kentsel aydınlar tarafından desteklenmiştir. Batılı, laik, otoriter ve uyguladığı ekonomik kararlar ile devletçi ve milliyetçi bu bürokratik ittifak, Kemalist devrimin öncüsü olmuştur. Bu Cumhuriyetçi-bürokratik elit, reformist olmaktan çok devrimcidir. Cumhuriyetin kurulması ve getirdiği değişim alabildiğine hızlı gerçekleşirken, toplumsal dönüşüm bir o kadar yavaş ve sınırlı olmuştur. Sosyal gruplar, özellikle de büyük köylü nüfusu, devletle zayıf bir şekilde ilişkilendirilmiş, katılımın dışında bırakılmış ve esasen kentin kendi geleneksel araçlarına güvenmeye bırakılmıştır (Sunar, 2004: 122). Merkez sağ parti iktidarları, yıllarca bu geçmişten beslenmiştir. Merkez sağın kurucu partisi DP muhalefeti, bunu açıkça dile getirmemiş olsa dahi Cumhuriyet devrimlerine karşı bir tepki cephesini harekete geçirmiştir. Milletten uzaklaşmış bir devlet yerine, milletin gerçek temsilcilerine devletin teslim edilmesi gerektiği üzerinden söylem geliştirmiş, bu nedenle de “yeter söz milletin" diyerek söze başlamıştır ( Mert, 2007: 103). DP'nin seçimlerde elde ettiği başarının belki de en önemli nedeni, gerek siyasi gerek ekonomik olarak topluma varlığını hatırlatması olmuştur. Durmaksızın köylülerin refahına çalışan ve yerellik vurgusu yapan DP, aynı zamanda CHP içinden ayrılmış milletvekilleri ve aydınlardan oluşmaktadır. DP bu yönüyle, Cumhuriyet tarihinde ilk kez bir siyasi partinin Türkiye nüfusunun çoğunluğuna doğrudan ulaştığını göstermiştir. Sonuç olarak, yöneten ile yönetilen arasındaki geleneksel boşluk kapanmaya başlamıştır (Szylıowıcz, 2017: 495). Cumhuriyet idaresinde oluşturan millet kimliği, DP ile yeniden oluşturulmaya çalışılmıştır. Türklük yine merkezde olmak ile birlikte, yerel değerler ve din yeni milli kimliğin temel unsurları olarak ifade edilmeye başlamıştır. DP muhalefeti, Cumhuriyetin seküler ulusçuluğuna karşı sağ milliyetçiliği üreterek bütün politikalarını milliyetçilik, muhafazakârlık ve din üzerinden kurmuştur. DP'yi takip eden AP ve sağ siyasette etkisi uzun yıllar konuşulan Süleyman Demirel, hep milleti iktidar yapmanın altını çizmiştir (Çavuşoğlu, 2009:268).

Merkez sağ, temel değerlerini Cumhuriyet devrimlerine karşı tepki üzerinden şekillendirirken, aynı zamanda 1lımlı ve uzlaşmacı politikalar geliştirmiştir. Aşırıcılığa karşı temkinli davranan merkez sağ partilerin liderleri de genelde liberal kanadın temsilcileri olmuştur. Parti içerisinde fazla milliyetçi-muhafazakâr kalanlar, liderlik yarışının ve zamanla siyasetin dışında kalmıştır. Farklı bir çevreden gelen ve sağ siyasetin temsilcilerinden Süleyman Demirel ile AP'de liderlik, belli ölçüde değişime 
uğramıştır. Demirel, aşırılıklara karşı daha temkinli bir tutum izlemiştir. Cumhuriyet devrimlerinin öngördüğü kimlik modeline sonuna kadar uyum göstermiştir ( Heper: 2011:248). 1964'ten 1971'e uzanan y1llarda, siyasete girdiği ilk günden beri kullandığ1 modern teknokrat imajı devam etmiştir. 60'lı yılların Demirel'i, öğrenci hareketlerine karşı toleranslı, ordu ile ilişkilerde ise yatıştırıcı olmuştur. Ülkeyi yönetirken hiçbir hususta partizanlaşmayacağını sık sık vurgulamış, komünizm savunucularına karşı tavrında dahi partizanlaşmaktan kaçınmıştır. 1970'lerde Demirel, gerek dönemin değişen ve sert koşulları gerek Ecevit'in Demirel karşısında yükselişinden ötürü olacak ki, daha sert ve kutuplaştırıcı söylemlerde bulunmuştur ( Arslan, 2019: 13). Merkez sağ partilerinin zaman içerisindeki değişimi ANAP ile devam etmiştir. 1980 askeri müdahalesi gerçekleşmiş, siyaset ANAP ile yeniden sivilleşme yoluna girmiştir (Mert, 2007: 107). ANAP'ın siyaseti yürütürken izlediği yol, öncüllerini takdir etmek ancak bunu öncüllerinin yöntemlerini kullanmadan yapmak olmuştur. Muhafazakârlı̆̆ı diğer partilerden farklı olarak benimsemiş, tüzük ve programında muhafazakârlığı, “milli ve manevi değerler"' kavramını kullanarak tanımlamıştır (Çavuşoğlu, 2009: 173). Turgut Özal liderliğindeki ANAP, orta sınıf gruplarını popülist politikalara başvurmadan merkez sağ koalisyona dâhil etmek istemiştir. 1983'te küreselleşen pazar kapitalizmine yönelik politikalar çerçevesinde üretken bir koalisyonu teşvik etmek için gayret etmiştir. Bunu yaparken orta sınıfların üretken olmayan muhafazakârlığına itiraz ederek; ancak onları terk etmeden üretken bir koalisyon oluşturmak istemiştir (Sunar, 2004: 130). Sadece ekonomide değişikliği hedeflemeyen Özal, 24 Ocak 1980 kararları ile 1980 öncesinde siyasette ve toplumda var olan 'devlet belirleyiciliği’ düşüncesini yerinden etmiştir. Özal kurduğu partinin hemen her görüşü kapsamasına özen göstermiş, sağ ve sol kavramlarını o güne kadar anlaşıldığı biçimiyle reddetmiş, "mukaddesatçı sağ”, "milliyetçi să̆", "liberal sağ” ve "sosyal demokrasi” olmak üzere dört farklı siyasi eğilimi birleştirmeyi hedeflemiştir ( Özdemir \& Demirkanoğlu, 2013:5).

ANAP'tan sonra, merkez sağ siyaset en büyük dönüşümü ve kırılmayı AK Parti ile yaşamıştır. Kendisini siyasetin merkezinde tanımlayarak “'muhafazakâr-demokrat' 'bir kimliğe sahip olduğunu ifade eden AK Parti, Türkiye'de ilk kez İslamc1 ve dindar muhafazakâr çevreden gelen politikacıların liderlik kadrosunu oluşturduğu bir merkez sağ siyaset örneğini hayata geçirmiştir (Mert, 2007: 108). AK Parti’ye kadar merkez sağ partilerin ve siyasetin kalkış noktası Cumhuriyet rejiminin Batılı kimlik politikalarına tepkisi üzerinden gelişme göstermiştir. Ancak, AK Parti’nin neredeyse tüm politikalarının AB üyeliği sürecine endekslenmesi, İslamcı geçmişinden dolayı yaşadığı meşruiyet krizini aşmak için dışardan destek bulmak olarak algılanmıştır (Mert, 2007: 113). Türkiye'de dini eğilimli siyasi kadrolar liberalleştikleri gibi, 'Milli Görüş gömleğini'” defalarca çıkardığını belirten AK Parti de giderek laik ve demokratik sisteme ayak uydurmaya başlamıştır ( Heper, 2011: 379). Ancak tüm bu dönüşüme karşın, Recep Tayyip Erdoğan ve AK Parti'nin zihniyet temellerinde İslami bir realitenin mevcut olduğu görülmektedir. Bunu AK Parti, toplumun kendi sembolleri ile özdeşleşmesinin gerekliliği üzerinden ifade etmiştir. AK Parti’yi diğer İslamcı partilerden ayıran temel özelliği ise, bundan önceki İslamcı partilerin parti politikalarından farklı olarak dünya ekonomisi ve liberalizm ile daha uyumlu bir duruş sergilemesi olmuştur ( Mardin, 2018: 196).

\section{MERKEZ SAĞ PARTILERIN IDEOLOJISI}

Merkez sağ, tarihi süreç içerisinde geçirdiği dönüşüme rağmen belirli ideolojik unsurlar üzerinden bir yol izlemiştir. Merkez sağ ideolojisi, milliyetçilik, muhafazakârlık ve İslamcılık olmak üzere üç temel unsura dayanmaktadır. Ancak bu merkez sağ partilerin her dönemde bu ideolojilere aynı mesafede durdukları anlamına gelmemektedir. Dönem dönem, bu ideolojilerden bazısı merkez sağ partilerin o dönemdeki reflekslerini ifade etmek için yeterli olmuştur. Kimi zaman tek millet, tek devlet diye politika geliştiren merkez sağ partiler, kimi zaman her türlü milliyetçiliğe karşı kontrollü bir tepki geliştirmiştir.

\subsection{Milliyetçilik}

Merkez sağın milliyetçilik anlayışı, Kemalizm'in milliyetçilik anlayışından ayrılmaktadır. Ulusalcılık olarak da adlandırılan Kemalist milliyetçilik, etnik milliyetçilikten farklı olarak Türkiye Cumhuriyet'inin sınırları içerisinde kalan vatana aidiyeti ifade etmektedir ( Çolak, 2017: 113). Merkez sağ ideoloji olarak milliyetçilik ise, Kemalist ve etnik milliyetçilikten ayrılmaktadır. Merkez sağ partileri genellikle "millet'” kavramı üzerinden milliliği tanımlar. Merkez sağ parti iktidarları milliyetçiliği, milleti ayrıştırıcı değil birleştirici bir unsur olarak görmüş ve özellikle siyasal kriz dönemlerinde, milli birlik vurgusu üzerinden söylem geliştirmiştir. Menderes, birçok konuşmasında milliyetçilik motiflerini öne çıkararak Vatan Cephesi'nin kurulması çağrısında bulunmuştur. "Demokrasi milli iradenin tecelli ettiği bir rejimdir ve Türk devletinin bekası, gücü ve itibarı buna bağlıdır' diyen Demirel de söylemlerinde sıkça milliyetçiliğe yer vermiştir. Merkez sağ partilerde hissedilen milli aidiyetin önemli bir yönelimi de Türkiye'deki devlet geleneği ile ilgilidir. Milliyetçilik, devleti milletle özdeşleştiren ve Türk devletinin milleti için var olduğu ve ondan ayrılmaz bir bütün olduğu anlamını taşımaktadır. Bu nedenle, merkez sağın milliyetçiliğe dayalı söylemleri, milli iradeye dayalı iktidar söylemleridir (Erken, 2016: 205).

Milliyetçiliği muhafazakârlıkla birlikte toplumun geleneksel değerlerini nitelemek için bir araç olarak kullanan merkez sağ milliyetçiliğini, “Türkiyelilik” olarak ifade etmek doğru olacaktır. Menderes’ten Erdoğan'a kadar tüm merkez sağ partilerin milliyetçiliği, etnik temelli bir milliyetçilik kurgusunun reddine dayanmaktadır. Farklılıkların birer zenginlik olduğunu ve Türkiye'nin farklılıklarıyla bir bütün olduğunu belirten merkez sağ, farklı etnik kimlikleri dışlamadığını gösterme eğiliminde olmuştur (Turku, 2018: 52).

\subsection{Muhafazakârlık}

Merkez sağın önemli ideolojik unsurlarından bir diğeri, muhafazakârlıktır. Merkez sağ partiler gerek bir tutum olarak, gerek ideolojik olarak muhafazakâr değerlerden beslenmektedir. Tarihin ve değerlerin önemli olduğu vurgusu sıklıkla merkez sağ partilerin söylemlerinde yer almakta ve merkez sağ partiler kendilerini muhafazakâr bir kimlik ile ifade etmektedir. Bu nedenle, DP'den sonra gelen AK Parti'de dâhil merkez sağ parti iktidarları kurulduğu günden bugüne, kendisini DP ve ANAP'ın devamı 
niteliğinde göstermekte ve kaynağını bu geçmişten aldığını söylemektedir. Sürekli bir medeniyet vurgusu ve Osmanlı Devleti’nin mirasçısı olunduğuna dair vurgu da bu durumun diğer göstergeleridir. Ancak, Türkiye'de merkez sağın bu tutumu, eski rejime geri dönüş ve saltanatı getirme düşüncesi anlamına gelmemektedir. Cumhuriyet'in en önemli unsurlarından olan halkın yönetime katılımı benimsenmiştir (Akkır, 2015: 108). Özellikle, çok partili hayata geçişle başlayan gruplaşma ve ayrışmalar, tek parti döneminde bir düşünce çizgisi olarak uç veren Kemalizm muhafazakârlığına, "yani ucu açık bir süreci başlatan bir kurucu edimden ziyade korunması gereken bir yapıyı kuran kurucu edim” (Bora, 2017:123) düşüncesine, alternatif bir muhafazakârlığın önünü açmıştır. Temelde farklı ve sıradan muhafazakârlığı temsil ediyor gibi görünen DP, tek parti döneminin değerler sistemini revizyona tabi tutmak için toplumu bürokratik merkeze karşı seferber etmiştir. CHP'nin halkın gözünde Batılılaşma, batılı yaşam biçimi ve geleneksel değerlerin yitimiyle özdeşleşmiş olmasına karşın, DP geleneği savunan liberal yapısıyla halka seslenmiştir ( Göka, Göral \& Güney, 2001: 302). Bu nedenle, Türkiye’de kurulan merkez sağ partilerin muhafazakârlık anlayışını belirli bir muhafazakâr kalıbı içerisine sığdırmak zordur. DP döneminden AK Parti dönemine kadar merkez sağ partiler, liberal açılımlar gerçekleştirmiştir. AK Parti, değişim ve dönüşümün doğal akışı dışında radikalizm ve toplum mühendisliği girişimleri ile gerçekleşebileceği fikrine karşı çıkarak, geleneksel yapının bazı değerlerini ve kazanımlarını koruyarak değişimi sağlamak gerektiğini savunmuştur (Suveren, 2016: 112). Bu nedenle, Türkiye'de merkez sağ partileri liberalmuhafazakârlık anlayışı içinde değerlendirmek daha doğrudur. Aynı zamanda bu liberal muhafazakârlık modeli, serbest piyasa ve teşebbüs hürriyeti, fikir, inanç ve vicdan hürriyeti, yerel yönetimlerin güçlendirilerek toplumun inisiyatifine yer açılması gibi hedefleri gerçekleştirmiştir. Bu model aynı zamanda devletin küçültülerek güçlendirmesi gibi liberal unsurlar ile devletin din ağırlıklı geleneksel davranış tarzlarına kamusal olarak saygılı olunacağını belirten özelliklere de sahiptir ( Köker, 2001: 288).

\section{3. İslamcilık}

Cumhuriyet kurulmadan önce Osmanlı’yı kurtarmak için bir çözüm önerisi olarak sunulan İslamcılık, Müslümanlara sadece bir kozmoloji olarak değil, aynı zamanda strateji ve taktikler olarak da çözüm sunacağ için bir kurtuluş yolu olarak gösterilmiştir. Cumhuriyet kurulduktan sonra öğretiler değişmiştir. Yeni öğretiler Batının örnek alınması gerektiği üzerinden şekillenmiş, yaygın olan İslami üslubun yerine konulabilecek bir şey önerilmemiştir (Mardin, 17: 164). Bu nedenle, zamanla toplumun kimi kesimlerince siyasal-kültürel iktidarın halkına yabancılaşmış bir azınlığın elinde olduğu düşüncesi ortaya çıkmıştır. 1950’li yıllardan beri sağ siyasal söylemlerin, “'halk muzdariptir', “" vatan gurbettedir', " 'halk gerçek temsilcilerine kavuşacaktır’” gibi değişik söylemlerle iktidarın milletin gerçek temsilcilerinin eline geçmesi gerektiği teması üzerinden destek bulması da bundan ötürüdür ( Mert,2007: 173).

DP'nin iktidara gedikten sonra dini politikalar adına aldığı ilk karar, ezanın Arapça okunmasının önündeki engeli kaldırmak olmuştur. DP ile ezanın yeniden Arapça okunmaya başlanması, DP'nin bundan sonra atacağı her adımda destek görmesini sağlayacak önemli bir icraat olmuştur. DP'nin bu desteğini kaybetmek istemeyen ve DP'nin izinden giden merkez sağ partiler, dini sembol ve değerleri muhafazakârlık zemini üzerinden yeniden inşa etmiştir. Merkez sağın, 1980'e kadar dini popülist bir söylem o3.2. larak iktidarı kazanma unsuru olarak kullandığı iddiası bu yüzdendir. DP'nin ve onun izinden giden merkez sağ partilerin din söyleminde aşırılıklardan kaçındı̆̆ı; ancak din konusunda 1lımlı bir hava oluşturmaya çalıştığ görülmektedir ( Kırkpınar, 2018:354). Ancak, 1980'lerdeki ve sonrasındaki siyasetçilerin dini siyasete alet ettiği fikri, mevcut siyasi politikaların değerlendirilmesi açısından yetersizdir. 1980 sonrasında siyasi ve ekonomik alanların ayrışmaya başlaması sonucu ortaya çıkan durum, dinin siyasete alet edilmesinden çok dinin nüfuzunun da dönüşmesidir. Yani, Türk-İslam Sentezi’nin sivil dine dönüşmesidir. Özellikle, Özal'ın öncülüğünü yaptığı ekonomik liberalizm ve bu sürecin İslam ile uyum içerisinde ilerlemesi İslam'ın sivil dine dönüşmesine yardımcı olmuştur (Mardin, 2017:166). Merkez sağı temsil eden AK Parti iktidarı da parti yöneticilerinin İslamcı bir sağ partiden ayrılarak gelmiş olmasından ötürü, başta meşruiyet krizi yaşamıştır. Ancak, AK Parti iktidarı döneminden sonra Türkiye'de siyasetin, sert çekirdekli ideolojiler ile yürütülemeyeceği anlaşılmıştır (Mert, 2007: 173).

\section{TOPLUMSAL HAREKETLER}

Devletlerin dahi tek karar alıcı konumda olmadığı dönüşen ve değişen dünyada, toplumsal sözleşmenin bir parçası olan bireyin bir karar alıcı olarak varlığı toplumsal varlığından zayıftır. Bu nedenle, toplumsal hareketler bir siyasi katılım aracı olarak, toplumsal sorunların devlete iletilmesi hususunda daha etkili bir iletişim aracıdır. Toplumsal hareketlerin etkisi, geliştiği toplumun karakteri içerisinde bir anlam kazanır. Kimi zaman devlet ile etkili bir iletişim aracı olarak anlam kazanırken, kimi zaman demokrasi için taşıdığı anlamın içi boşalır.

\subsection{Demokrasi ve Toplumsal Hareketler}

Toplumsal hareketlerin demokrasi ile olan ilişkisi ve demokrasiyi besleyen bir unsur olarak var olup olamayacağı, toplumsal hareketlerin tanımlanması ile doğrudan ilişkilidir. Toplumsal hareketler, çeşitli çıkar gruplarından oluşan birçok farklı toplumsal kesimi içerisinde barındıran bir siyasal katılım biçimidir. Bu farklı kesimler arasında; işçiler, kadın grupları ve öğrenciler, kimi zaman da entelektüel kesim ve aydınlar yer almaktadır. Toplumun bu farklı çıkar grupları çoğu zaman farklı şikâyetler etrafında bir araya gelmektedir. Ancak, çoğu zaman bu söz konusu şikâyetler, politik ortamda demokrasi eksikliği ile ifade edilmiştir ( Tilly, 2008: 13). Toplumsal hareketler, demokrasinin işlerliğini arttıran ve vatandaşların taleplerini dile getirdiği alternatif unsurlardan biri olarak ifade edilmektedir. Bunlarla beraber, bulunduğu toplumda ne kadar çok vatandaşın taleplerini dile getirebildiği, eşit ve farklı vatandaşlar tarafından dile getirilen bu taleplerinin devlet davranışları üzerindeki etkisi, bu hakların ve taleplerin devletin koruması altına ne ölçüde alındığı önem arz etmektedir ( Porta, 2005: 13).

En basit haliyle seçilen temsilcilerin düzenli seçimler yoluyla vatandaşlara karşı sorumlu olduğu belirli bir karar verme yöntemi olarak tanımlanan demokrasi, topluma alternatif bir temsil hakkı veren toplumsal hareketler ile etkinlik alanını genişletir. 
$\mathrm{Bu}$ açıdan toplumsal hareketler, seçilmişlerden farklı olarak, taleplerini dile getiren ve demokrasi değerlerini besleyen yeni çıkar grupları olarak ifade edilmektedir ( Porta, 2005: 337). Ancak, toplumsal hareketler her zaman demokrasiden yana olmazlar ya da demokrasiyi teşvik etmezler. Toplumsal hareketler, kimi zaman demokrasi taleplerinden daha çok, farklı çıkar ve şikâyetler etrafında örgütlenmektedir. Bu örgütsel yapıların işleyişi, demokrasinin uygulamada iyi işlediği toplumlara oranla demokrasinin zayıf olduğu toplumlarda farklı sonuçlar doğurmuştur. Demokrasinin işlerliğinin zayıf olduğu ve derinleşmediği toplumlarda, demokrasiye katkı sağlaması beklenen toplumsal hareketler, demokrasiden uzak karşıt hareketleri doğurmuştur. Özetle, demokrasi ile toplumsal hareketlerin örtüşemediği koşullarda toplumsal hareketler, antidemokratik programların yürütülmesine, dinsel, ırksal ve etnik azınlıkların dışlanmasına neden olmuştur (Tilly, 2008: 197).

\subsection{Siyasete Katılım Aracı Olarak Toplumsal Hareketler}

Temelde toplumsal sorunlar ve çatışmalardan doğan muhalefet, bazı somut durumların varlığı söz konusuyken de bir eyleme, görüşe veya tutuma karşı ortaya çıkan kimseler topluluğu olarak ifade edilmektedir. Siyasal iktidarın halkın beklentilerini karşılayamadığı, iktidarın toplumsal sorunlara çözüm getiremediği, ekonomik durumun zayıfladığı, iktidarı elinde bulunduranların yanlış politika izledikleri, ulusal ve uluslararası kriz dönemleri, muhalefetin ortaya çıkmasına neden olan somut durumları oluşturmaktadır. Muhalefetin resmi aracı parlamentolar olmakla birlikte, muhalefet parlamentolar dışında örgütlüörgütsüz çeşitli grup ve topluluklarca yasal ve yasal olmayan yollarla varlık göstermektedir (Nişancı, 2003: 275). Toplumsal hareketler ile ortaya çıkan muhalefet, siyasal iktidara alternatif oluşturmak üzere geliştirilen bir proje olarak değil, çoğu zaman demokrasiyi geliştirecek, toplumu bu yönde dönüştürecek bir muhalefet olarak ortaya çıkmaktadır (Caniklioğlu, 2007: 111). Bireylerin bazen dolaylı olarak bazen doğrudan kendilerini ifade etmeye ve taraf olmaya ihtiyaçları vardır. Bu doğrultuda meydana getirdikleri örgütlenme eylemi, hem farklılıkların bir araya gelebilmeleri hem de benzerliklerin kesişimi sağlaması açısından önemlidir (Doğan, 2002: 246).

Toplumsal hareketler, hedef otoritelere yapılan ortak hak talebi kampanyaları, yürüyüşler, halk mitingleri, gönüllü birlikler, dilekçeler, afişler ile varlığını göstermektedir. Kimi zaman ise sanat, sinema ve medya araçlarına yansımaları ile kamu politikalarına katılımcı olarak dâhil olmaktadır. Bu araçların tamamı, siyasi katılım sağlamak içindir (Erdemir, 2011: 201). Düzenli olarak gerçekleştirilen seçimler ile toplumun siyasete katılımı belirli ölçüde gerçekleştirilmekle birlikte, siyasi katılım alanları azınlık hakları, cinsiyet ayrımcılığı, kültürel ve etnik farklılıklar yüzünden meydana gelen sorunların çözümünde yeterli değildir. Çoğunlukçu demokrasi modelinin sağladığı temsil hakkı, kimi zaman seçmenler ile temsilcilerin uyuşmazlığı kimi zaman iktidarın tüm yönetim organlarını ele geçirmesi gibi nedenlerden ötürü siyasi katılımı kısıtlamaktadır (Öngör, 2018: 39). Toplumsal hareketler ise bazı temel özellikleri ile demokrasiyi beslediği gibi, gelişmiş bir demokrasi de bir siyasi katılım aracı olarak toplumsal hareketlerin oluşmasını ve serpilmesini destekler. Siyasi katılım aracı olarak toplumsal hareketlere en etkili örnek ise, kitlesel protesto gösterileridir. Protesto tipi örgütlenmelerde meydana gelen toplumsal hareketler, siyasal kararların alınmasında etkili olmuştur. Hiçbir zaman çevre hareketlerinin resmi bir siyasi temsilcisi olmadığı halde, nükleer enerji ve çevre konularında kampanyalar ile başlayan protesto örgütlenmesi, yeşil partilerin ortaya çıkışını sağlamıştır. Toplumsal hareketlerin, hak talebinde bulunmayı kolaylaştıran siyasi partiler ve sendikalardan farklı olarak bu kurumların kurulmasını teşvik etmesi açısından önemli itici güç oldukları görülmektedir (Porta ve Diani, 2006: 148). Ancak, toplumsal hareketlerin bir siyasal katılım aracı olarak demokrasiyi destekleyebilmesi için bazı temel süreçlere ihtiyaç vardır. Bu süreçler: vatandaşlar ile devlet arasındaki tekil veya aracı ilişkilerden doğrudan ve kategorik ilişkiye geçişi sağlayan, siyasi aktörler arasındaki ilişkileri eşitleyen ve genişleten, sosyal eşitsizliklerin kamu politikasına sızmasını azaltan ve güven ağlarının kamu politikasına uyum sağlamasını pekiştiren süreçlerden oluşmaktadır ( Tilly, 2008: 218).

\section{TÜRKIYE'DE TOPLUMSAL HAREKETLER}

Tek partili siyasal sistem, toplumun dönüştürme kapasitesinin üstten geldiğini varsayarak, toplumdan bağımsız şekilde işleyen ayrıcalıklı bir egemen olarak hareket etmiştir. Bu süreçte, kimin siyasete dâhil olup olmayacağına dair sınırları belirleyenler de sistemin kurucuları olmuştur. Ulusal çıkarlar ile devlet çıkarı arasında, devlet ile millet arasında siyasal, sosyal ve kültürel bir bütünlük olduğu varsayımı üzerinden hareket edilmiştir. Bu nedenle, Türkiye'de toplumsal hareketler bu siyasal sistemin bir ürünü olarak 1980'lere kadar, devlet merkezli ve kontrollü olarak varlığını sürdürmüştür. Yine, Türkiye'de meydana gelen toplumsal hareketlerin şekillenmesinde dâhili ve harici birçok gelişme etkili olmuştur. Bu açıdan, Türkiye'de meydana gelen toplumsal hareketlerin oluşum süreci ve özellikleri farklılık göstermekle birlikte, modernleşme ve kentleşmenin etkisi ile Batıdakine benzer bir gelişme göstermiştir.

\subsection{Toplumsal Hareketlerin Oluşum Süreci}

Türkiye'de toplumsal hareketlerin bir siyasal katılım aracı olarak karşılık bulması, belirli toplumsal ve siyasal dönüşümler ile ortaya çıkmıştır. 'Sivil' kelimesi kökeni itibari ile şehirleşme ve şehir hayatının getirdiği görev ve yükümlükleri ifade etmektedir (Mardin, 1995: 9). Türkiye'de sivil siyaseti oluşturan toplumsal hareketler şehir hayatının bir ürünü olarak ortaya çıkmış, siyasal ve sosyal değişmelerin yaşandığı çok partili hayata geçiş ile önemli hale gelmiştir. Türkiye'de modernitenin inşa ettiği temel değerler ve devlet merkezci örgütsel yaşamın hâkimiyeti, 1950’lilere kadar varlığını korumuştur. Sadece içerde yaşanan siyasal gelişmeler değil, aynı zamanda II. Dünya Savaş’1 sonrasında demokratik liberal sistemin dünyada yaygınlaşması sonucu özgürlükler, temel insan hakları ve hukuk devleti gibi kavramlar evrensel boyutta bir anlam kazanmıştır. Zamanla kamu bürokrasisinin siyasal alandaki etkisi aşınmaya başlamıştır. Liberal ekonomik sistemin gelişmesi ile artan sivil örgütlenmeler sosyal hayattaki örgütlenmeleri de önemli ölçüde etkilemiştir (Tuncel, 2011:292). 
Çok partili parlamenter sisteme geçiş ile birlikte ekonomik hayatın belirli bir seviyeye kadar liberalleştiğii, toplumsal hareketlerin sağ-sol ekseni üzerinde organize olmaya başlanıldığı izlenilmekle birlikte (Keyman, 2006: 22), 1950’lerden sonra giderek elitist çizgiden uzaklaşan sivil toplum hareketleri 'halk' adına ortaya konmaya çalışılan bir meşruiyet arayışı içerisinde olmuştur. Bu zamandan sonra ortaya çıkan toplumsal hareketlerin toplumsal sorunlar ile ilgi olduğu gözlemlenmektedir. Kimi zaman iktidar karşıtı bir muhalefet aracı, kimi zaman devlet ve bürokrasisi ile bir ittifak arayışı olarak ortaya çıkan toplumsal hareketler kimi zaman ise, siyasetin dışına kayma eğilimi göstermiştir. Toplumsal hareketlerin ve sivil toplum unsurlarının bu eğilimler etrafında şekillenmesinde en önemli neden ise, siyaseti meşru görmemeleri ve toplum kesimlerini temsil eden ve dönüştürmeye çalışan sivil toplum hareketlerinin, devlet veya bürokrasi karşısında zayıf kalması olmuştur ( Gümüş, 2004: 3). İktidara karşı gelişen ve 1960 Askeri Müdahalesi 'ne kadar devam eden öğrenci hareketleri, sol cenah tarafından iktidara karşı kazanılan başarının sembolü haline gelmiştir. Sol görüşlü bazı düşünürlerce, iktidar değişikliği meydana gelen toplumsal hareketlerin başarısı olarak gösterilmiştir. Yine, siyasi iktidarın hareket alanının Milli Güvenlik Kurulu aracılığıyla sınırlandırılması amaçlanırken, 1961 Anayasası ile toplumun değişik kesimlerinin sosyal alanda özgürce örgütlenmesinin önü açılmıştır. Ancak, bu düşünce fazla uzun sürmemiştir. Özellikle, tüm dünyayı etkisi altına alan sosyal ve siyasal hareketlerin oluşmaya başladığı "68 Olayları” neticesinde sosyal alandaki toplumsal örgütlenmelerin kendilerine çizilmiş sınırların dışına çıktığı düşüncesi oluşmaya başlamıştır (Tuncel, 2011:304). Bu nedenle 12 Mart 1971 Muhtırası'na ihtiyaç duyulmuş, Muhtıra sonrası yapılan anayasa düzenlemeleri ile yasalar, kamu bürokrasisinin ihtiyaç gördüğü şekliyle yeniden gözden geçirilmiştir. Düzenlemeler ile siyasal alanın daraltılmış ve sosyal alandaki özgürlükler yeniden kısıtlanmıştır. Bu nedenle, 1971 yılından sonra toplumsal örgütlenmeler bu örgütlerin bastırılması sonucu yasal olmayan bir alanda faaliyet göstermeye başlamıştır. Muhtıra döneminde ve sonrasında toplumun bazı kesimleri şiddeti, siyasal ve sosyal alanda kendilerini ve farklılıklarını ifade edebilecekleri bir araç olarak kullanmaya başlamıştır. Türkiye'de meydana gelen toplumsal hareketlerin sonucu olarak askeri müdahaleler ile oluşan kamu bürokrasisi bir yandan şiddetin süreklilik ve yaygınlık kazandığı bir ortamı hazırlarken, bir yandan da kendisi toplumun değişik kesimlerine yönelik uyguladığı şiddeti meşru gösterecek bir zemin hazırlamıştır (Tuncel, 2011: 285).

1960 sonrasında belirli saflara ayrılan toplumsal hareketlerin belirmeye başladığı dönemin 1950’ler olduğu değerlendirilmektedir. Daha sonraki dönemlerde boy gösterecek olan milliyetçi, muhafazakâr, dindar, liberal, demokrat, sosyal demokrat ve sosyalist akımların ve yine feminist faaliyet gösteren birçok grubun temelleri bu dönemde atılmıştır. Toplumsal hareketlerin devletten bağımsız sivil hak ve özgürlükler temelli yeni örgütsel yaşamın aktörleri olarak ortaya çıkması, 1980 ve sonrasında mümkün hale gelmiştir. Bu gelişmeler, 1980’lerden sonra Türkiye'de meydana gelen köklü ekonomik ve kültürel değişikliklerin bir sonucu olarak gerçekleşebilmiştir (Keyman, 2006: 22).

\subsection{Toplumsal Hareketlerin Özelliği}

Ortaya çıkışı, amacı ve meydana getirdiği sonuçları Batı'da sivil toplumun ve demokrasinin oluşmasında önemli rol oynayan toplumsal hareketler, Türkiye'de uzun bir süre askeri topluma karşılık kullanılmıştır (Mardin, 1995: 9). Türkiye'de toplumsal hareketler, demokrasinin sık sık askeri müdahale aracılığıyla kesintiye uğradığı, askeri iradenin ve gücün toplumda sürekli hissedildiği, resmi olmayan bir muhalefet unsuru olarak geliştiği darbelerin nedeni ya da meşru sonucu olarak yorumlanmıştır. Bu nedenle, Türkiye'de toplumsal hareketler kendiliğinden ve siyasal katılım ihtiyacından ortaya çıkmış varlıklar olarak değil, belli bir ideolojiye hizmet eden, bilinçli bir sivil toplum oluşturma iradesinin ürünü olarak algılanmış, demokrasinin işlerliğini sekteye uğratacak antidemokratik hedefler olarak görülmüştür (Caniklioğlu, 2007: 111).

1968'lere kadar gençlik hareketleri CHP denetiminde ve Kemalist çizgidedir. Bu yıllardan sonra iki kutuplu dünya düzenin meydana getirdiği siyasi kutuplaşma Türkiye'deki gençlerin Kemalizmden uzaklaşarak, kapitalizme karşı sosyalizme inanan ve güvenen bir gençliğe dönüşmesine neden olmuştur (Göktolga, 2005: 950). Türkiye'de öğrenci hareketleri olarak başlayan toplumsal hareketler, iktidardaki DP'ye karşı, darbenin gerçekleştiği 27 Mayıs’a kadar meydanlardan ayrılmayan öğrencilerin yürüyüşleri ile ortaya çıkmıştır. İlk etap hareketlerinin ve örgütlerinin karakteri, Atatürk ilkelerini ve Cumhuriyet değerlerini korumak ve yaşatmak olmuştur. Bu gençlerin, "Hürriyet, hürriyet, Menderes istifa et" protestolarının yanında en dikkat çekeni “Ordu ile genlik el ele' 'dir. Atatürk değerlerinin DP hükümeti ile yerinden edildiğine inanan gençler, kendilerini Cumhuriyet döneminin atanmış muhafızları olarak görmüştür (Önkibar, 2019: 78). Ancak, 1968 yılında meydana gelen öğrenci hareketleri daha çok să̆ ve sol çizgide kendilerini konumlandıran gençlerin eylemlerinin başlangıç yılıdır. Öğrenciler örgütlendikleri cemiyetlerde faaliyet göstermekle kalmamış üniversiteleri, faaliyetlerini ve eylemlerini gerçekleştirebilecekleri alanlar olarak görmüştür. Bu dönemde üniversiteler sağ ve sol ideolojiyi benimseyen öğrencilerin çatışma alanına dönüşmüştür ( Koca, 2018: 98).

2000'li yıllarda meydana gelen en dikkat çekici toplumsal hareket ise, 2013'te, İstanbul'un tarihi, mimari ve çevre dokusunun yaşamı olumsuz etkileyecek bir biçimde değiştiğini savunan ve toplumun farklı kesimlerinden oluşan kişiler tarafindan meydana gelen toplumsal harekettir. 2013'te gerçekleşen ve "Gezi Olayları' olarak adlandırılan bu toplumsal hareket, Taksim'deki Gezi Parkı'nın bulunduğu mekâna hükümet tarafından, bir topçu kışlası yapılması düşüncesini protesto etmek amacıyla başlamış, başka illeri de içine alan ve aylarca süren bir harekete dönüşmüştür. İstanbul'da süren imar uygulamalarının çevreye yeterince zarar verdiği, mekânın içerisinde yer alan ağaçların kesilmemesi gerektiği, mekânın bir alışveriş merkezine dönüştürülmemesini talep eden ve Gezi Parkı'nı mekân tutmuş kişiler tarafından başlayan olaylar, gittikçe farklı taleplerle büyümüştür (Kalaycıoğlu, 2019:1). 


\subsection{Toplumsal Hareketlerin Talepleri}

Çok partili hayata geçişe kadar etnisite, sol, din ve liberalizm de dâhil olmak üzere bu unsurlar birer tehlike olarak görülmüştür. Sosyal ve siyasal alanda kısmi bir özgürleşme sürecine ancak 1946 yılında girilmiştir Bu özgürleşme alanı toplumsal kesimlerin seslerini yükseltebilecekleri toplumsal hareketlerin oluşumunun da önünün açmıştır ( Tuncel, 2011: 80). Bu tarihten sonra ortaya çıkan toplumsal hareketlerin farklı özellikler içermesine rağmen temel talepleri demokrasi olmuştur. 1960 öğrenci olaylarının ortaya çıkış nedeni, toplumda DP'den rahatsız olan kimi kesimlerin, DP iktidarına karşı duyduğu rahatsızlığın dışa vurumudur. DP iktidarının 1954 seçimlerinden sonra başlayan 1957 seçimlerinden sonra üniversiteler ve muhalefet üzerinde artan baskısı, ekonomik durumun bozulması, DP iktidarına karşı bir rahatsızlık yaratmıştır (Yaş, 2017: 200).

Türkiye'de modernleşmenin ilk dönemlerinde daha çok ekonomik çıkar eksenli ve siyasal gücü ele geçirmek veya etkilemek üzere ortaya çıkan toplumsal hareketler, zamanla değişme göstermiştir. 1980'lerden sonra daha çok hava kirliliği, sağlık ve çevre, kadın hakları, etnik ve dini haklar gibi tüm dünyada dikkat çeken konularla ilgili taleplerin dile getirildiği toplumsal gruplar, devlet üzerinde etkili olmaya çalışmıştır. Özellikle, 1970'li yıllardan sonra çevre konularının uluslararası platformlarda tartışılmaya başlaması ile Türkiye çevre politikaları konusunda ulusal anlamda etkilendiği gibi toplumsal hareketlerin etkisi ile yerel anlamda da etkilenmiştir (Çaha, 2016: 274).

\section{MERKEZ SAĞ PARTI İKTIDARLARININ TOPLUMSAL HAREKETLER ÜZERINDEN DEĞERLENDİRILMESI}

Merkez sağ parti iktidarlarının toplumsal hareketlere yaklaşımının değerlendirilmesi aynı zamanda merkez sağ parti iktidarlarının toplumsal hareketleri yorumlama biçimi ile ilişkilidir. Merkez sağı temsil eden DP, AP, ANAP ve AK Parti'nin iktidarı döneminde meydana gelen toplumsal hareketleri yorumlama biçimleri ve yaklaşımları somut gerekçeler sunması açısından önemlidir.

\subsection{Merkez Sağ Parti İktidarlarının Toplumsal Hareketleri Yorumlama Biçimi}

1945 yılında, çok partili hayata geçilmiş, TBMM öncülüğünde Türkiye'de iktidarın vatandaşın hür iradesiyle ve millî hâkimiyet esasına göre tayin edilmesi prensibi DP'nin kuruluşuna temel teşkil etmiştir. 1950'de bu usulle iktidara gelen DP, takip etmiş olduğu gayeyi bizzat göstermiştir. Türk milleti de sonra, birbirini takip eden iki büyük seçimle DP'yi iktidarda bırakmakta kararlı olduğunu göstermiştir. Halkın bu kararlı davranışı karşısında iktidarı demokratik yolla elde edemeyeceğini düşünenler, içinde bulundukları siyasi oluşumları, Türk milletinin kanuni iktidarını gayrikanuni yollarla düşürmek için mücadeleye sevk etmiştir (Arslan, 2009: 356). DP, iktidara geldiği günden beri bu mücadelenin farkındadır. Bu nedenle DP, iktidarını gayrikanuni yolarla değiştirecek her türlü eyleme engel olmaya gayret göstermiştir. Ancak tüm gayretine rağmen, 1954 seçimlerini yeniden kazanması sonrasında çoğunluğunu öğretim üyeleri ve onların harekete geçirdiği öğrencilerin oluşturduğu muhalefeti engelleyememiştir. Merkezi Ankara ve İstanbul olan ve sokağa taşan öğrenci hareketleri, gerek iktidarı gayri resmi yollarla teslim etmek istemeyen DP iktidarının sert tepkisi ve uygulamaları, gerek iktidarı gayrı resmi yollarla değiştirmek isteyenlerin mücadelesi nedeni ile ciddi boyutlara ulaşmıştır. Bu durum, 27 Mayıs 1960 Askeri Müdahalesi 'ne kadar devam etmiştir (Çaha, 2016: 236). Menderes, bu dönemde meydana gelen hareketlerin düşmanca olduğunu dile getirmiştir. Bu hareketin içerisinde bazı partilerin ve güçlerin olduğunu belirtilerek, bu kişilerin düşman ile işbirliği içerisinde bulunan küçük bir zümre olduğunu sözlerine eklemiştir. Menderes bu olaylarda öğrencilerden çok, CHP'ye tepki göstermiştir. Söylemlerinde, toplumsal hareketin bizzat içerisinde faaliyet gösteren öğrencilerin ise, kandırılmış ve aldatılmış olduğunu ifade etmiştir. Hareketin büyümesi sonucu bir radyo programından yaptığı konuşmada, olayların dedikodu, yalan ve şayia aracılığıyla çıkartıldığı ve büyütülmek istendiğini dile getirmiştir. Son zamanlarda ise olayların bir asilik ve isyan hareketi olduğunu sık sık dile getirmiştir ( Yaş, 2017: 213).

Demirel, DP hükümetinin yaşadığı siyasi tecrübeyi iyi okumuş olduğundan hükümete geldiği andan itibaren tedbir almıştır. 1965 'te Demirel hükümeti devraldığında orduya karşı temkinli davranarak ve danışarak hareket etmiştir. Demirel, Türk Silahlı Kuvvetleri'nin 2. Genel Kurmay Başkanı Cevdet Sunay’ın Cumhurbaşkanlığını onaylayarak hem ordu ile denge politikası yürütmeyi hem de köşk ile sorunsuz ilişkiler kurmayı hedeflemiştir. Yine, Sunay’1 Cumhurbaşkanlığına yollayarak ordunun partisi ile husumetine son vereceğine ve yeni bir ihtilal korkusunu da ortadan kaldıracağına inanmıştır. 1965'den sonra enflasyon oranlarının \%5 olduğu bu dönemde, Demirel hükümeti ile ekonomi istikrarsızlıktan kurtulmuştur. İkinci Kalkınma Plan21 ile özel sektörde teşvikler artmaya başlamış ve liberal ekonomi gelişme göstermiştir. Ekonomik canlılık, sosyal yaşama da yansımıştır. Sendikalar, dernekler ve üniversiteler de bu gelişmeler ile bir canlılık kazanmıştır. Böyle bir dönemde, Avrupa'da bozulan ekonomi ve işsizlik nedeni ile gelişme gösteren 68 Olayları'nın yaydığı yeni düşünce ve fikirler, Türkiye'de Menderes İktidarını deviren öğrencilerin kendilerini devrimin ve değişimin öncüsü olarak görmelerini sağlamıştır. Daha önce hiç bu kadar politize olmamış öğrenciler, üniversitede yeni haklar ve daha fazla özgürlük talep etmiştir. Sağ-sol ekseninde gelişen bu olaylar, içinden çıkılmaz boyutlara ulaşmıştır. Demirel'in tüm gayretine rağmen, bu olaylar da bir askeri müdahale ile sonuçlanmıştır. 12 Mart 1971 Muhtırası sonrasında yapılan anayasa değişiklikleriyle daha evvel 1961 Anayasası ile verilen özgürlüklerin bir kısmı geri alınmıştır (Birand vd., 2017).

Son olarak, 28 Mayıs - 15 Haziran 2013 günleri arasında Taksim Gezi Parkı'nda başlayan gösteri, yürüyüş ve protesto eylemleri zamanla İstanbul'a ve diğer illere yayılmıştır. Bu eylemler, Gezi Parkı'nın kışlaya dönüştürülmesi projesi üzerinden ortaya çıkmış olmakla beraber, sürecin birçok nedeni içerisinde barındırdığı görülmüştür. Gezi Olayları, AK Parti Hükümeti tarafından, demokratik oyla seçilen bir hükümeti yasal olmayan yollarla devirmek için bazı güçler tarafından gerçekleştirildiği şeklinde yorumlanmıştır. Hükümet, bu güçlerin CHP ve onun örgütlediği kitleler; bu hareketin de aynı aktörlerce ortaklaşa 
örgütlenen bir hareket olduğunu ifade etmiştir. Bu görüşlerin yanı sıra olayların nedeni, çevrecilik, laikliğin korunması, Atatürk’e sahip çıkma, demokratikleşme talepleri, üst statü gruplarını gecikmiş demokratikleşmesi gibi farklı şekillerde yorumlanmıştır (Kalaycioğlu, 2019:1).

\subsection{Merkez Sağ Parti İktidarlarının Toplumsal Hareketlere Yaklaşımı}

DP iktidarının 1960 öğrenci olaylarına yaklaşımı sert ve bastırıcı olmuştur. Tahkikat Komisyonu'nun karar ve tasarrufları arasında gazete ve matbaaların kapatılması, yayın yasakları, siyasi toplantıların yasaklanması, meclis müzakerelerinin yayınlanması yasağı, posta maddelerine el konulması ve tazyik hapsi gibi yaptırımlar bulunmaktadır. Kısaca bahsedilenler mevcut iktidara karşı sokağa dökülen gençliğe, DP iktidarının siyasal tutumunu göstermektedir. Tahkikat Komisyonu meselesi ise, 27 Mayıs 1960 Askeri Müdahalesi’ni etkileyen bir mesele olarak görülmüştür. Ancak, bu mesele DP açısından müdahalenin meşrulaştırılmasında kullanılan en önemli olaydır (Arslan, 2009: 356). Menderes, bu dönemde çoğunluğu öğrencilerden ve üniversite hocalarından oluşan grupları, "nifak cephesi” olarak adlandırmıştır. Bu cepheye karşı kendileri tarafından oluşturulan ve "Vatan Cephesi" adıyla siyasi atmosferin iktidar lehine korunması ve yeniden tesis edilmesi adına bir oluşuma gidileceği fikri, DP'lilerden tarafından kabul görmüştür. İktidarın yönettiği ve kamusal imkânların kullanarak devam ettirildiği bu süreç, gerek DP'lilerin gerek muhalefetin tesiriyle hızla yozlaştırılmıştır. Konuşması radyolardan yayımlanan Menderes, olayları çıkartanların düşmanlarla el ele vererek yalan haberler yaydıklarını ve ülkede karışıklığa neden olmak istediklerini belirtmiştir. Menderes, halka bu karışıklığa sebep olanların derhal yetkili makamlara bildirmesi gerektiğini, ayrıca, vatandaşlardan hiçbir yardımı esirgemeden zabıta kuvvetlerine yardım etmeleri gerektiğini belirtmiştir. DP'nin olaylara yaklaşımı bu şekilde olmuş ve ülkede artan kutuplaşma eğilimini tırmandırmıştır (Yaş, 2017: 98).

Demirel Hükümeti ise, 1968 Olaylarında DP'den daha sakin bir tutum sergilemiştir. Demirel, 6 Ocak 1970’teki AP grup toplantısında konuyla ilgili olarak, olayların anarşiye hizmet ettiğini ve devletin bu nedenle üzerine düşeni yapacağını belirtmiştir. Konuşmasının devamında, endişelenmeyi gerektirecek herhangi bir durumun olmadığını, gençlik örgütlerinin maddi çıkar amacı ve daha iyi şartlarda eğitim amacı ile seslerini yükselttiklerini dile getirmiştir. Buradan, Demirel'in söylemlerinin yatıştırıcı olduğu görülmektedir. Demirel olayların büyümesi sonrası yaptığı konuşmalarda, üniversitelerde anarşiye kesinlikle izin verilmeyeceğini , "Halka dönük üniversite" söyleminin ciddi boyutlara ulaşan öğrenci eylemleri karşısında anlamını yitirdiğini belirtmiştir (Koca, 2018: 106). Bu söylemlerin üzerinden çok geçmeden AP Hükümeti, 12 Mart 1971 tarihinde Türk Silahlı Kuvvetleri'nin verdiği muhtıra ile istifa etmeye zorlanmıştır. Yaşananlar neticesinde, öğrencilerin şiddet yoluyla hak arama talepleri amacına ulaşmamıştır. Siyasal otoritenin olayın tarafı olarak sürece karşı tedbir almasına müsaade edilmeden, hareket bir darbe ile kuvvet kullanarak bir süreliğine bastırılmıştır. Öğrenci hareketleri birkaç sene sonra şiddet düzeyi artmış bir şekilde yeniden ortaya çıkmıştır. Tekrar ortaya çıkan öğrenci hareketleri, yeni bir darbenin gerekçesi sayılarak 12 Eylül 1980 Askeri Müdahalesi sonuçlanmıştır (Birand vd., 2017).

İç ve dış basında hükümete karşı bir muhalefet gibi yorumlanan Gezi Olayları ile AK Parti iktidarının olaylara yaklaşımı, 1960 Öğrenci olayları ve DP iktidarının olaylara yaklaşımı ile benzerlik göstermektedir. Bu muhalefeti ve eylemleri tanımlarken Erdoğan'ın olayları daha çok ideolojik olarak ele aldığı ve küçümser tavrı nedeniyle kitleleri daha çok kışkırttığı yönündeki ifadeler basında sıklıkla yer almıştır. Yine basında yer alan ifadeler ile Gezi olaylarının Erdoğan'ın getirdiği yasaklara karşı bir tepki niteliğinde olduğu ve hiçbir ideolojik yapı ile bağlantısı olmadan taleplerini dile getiren bir kitle tarafından gerçekleştirildiği dile getirilmiştir. Erdoğan ise yaptı̆̆ı basın açıklamasında: “ ... Bütün illerde bu ideolojik yapıların uzantıları vardır. Ana muhalefet partisinin bütün toplumda, Türkiye'nin genelinde temsilcileri var. Onları ayağa kaldırmış olabilir, onları bu işe sürmüş olabilir. Aşırı uçların aynı şekilde belli illerde yapılanmaları var, onlar devreye girmiş olabilir. ..." şeklinde devam eden konuşmasında hükümetin iktidarı süresince yaptığı hizmetleri dile getirerek muhalefet oluşturmak için hiçbir gerekçelerinin olmadığını belirtmiştir. Olaylara karşı hükümetin yaptığı uygulamaların, gelişmiş ülkelerde yapılan uygulamalardan hiçbir farkı olmadığını ve bu uygulamalara devam edeceklerini sözlerine eklemiştir (Habertürk, Haziran 2013).

Rumeli Türkleri Kültür ve Dayanışma Derneği’nin Genel Kurulu'nda yaptığı konuşmada Erdoğan, yine ana muhalefeti eleştirmiştir. Konuşmasında, geçmişte de hükümetleri tehdit etmek için bu olayların benzerlerinin yaşandığını, bu yöntemlerin sandıkta başarı sağlayamayanların direniş çağrısı yaparak, bir kargaşa ortamı oluşturarak, demokrasi dışı müdahalelere zemin hazırlamak için tertip edilen tuzaklar olduğunu belirtmiştir (Sabah, 3 Haziran 2013). Diğer merkez sağ parti iktidarlarından farklı olarak, Erdoğan, Gezi Olayları devam ederken Gezi Heyeti ve gezi olaylarını destekleyen sanatçılarla bir görüşme yapmıştır. $\mathrm{Bu}$ görüşmeden sonra yapılan açıklamada hükümetin yargı kararlarına bağlı kalacağı belirtilmiştir. Eğer yargı süreci sonunda Gezi Parkı'na kışla yapılmaması kararı çıkarsa buna uyacaklarını, karar kışla yapılacağı yönünde çıkarsa Hükümetin referanduma gitmek istediği ifade edilmiştir (NTV, 13 Haziran 2013)

\section{SONUÇ}

Toplumsal hareketlerin en temel amacı, siyasi karar alıcıları etkilemektir. Bireylerin alınan siyasal kararlar karşısında verdiği onaylar ve retler bir siyasal katılım aracı olarak her zaman oy verme eylemi ile gerçekleşmez. Bu gibi durumlarda kitlesel protesto eylemlerine kadar uzanan eğilimler ve tepkiler toplumsal hareketleri meydana getirir. Ülkemizde de çoğunlukla kitlesel protesto eylemleri olarak meydana gelen toplumsal hareketler ve merkez sağ parti iktidarlarının toplumsal hareketlere yaklaşımı, benzerlik göstermektedir. 28-29 Nisan 1960 Olayları ile Gezi Parkı Olayları, olaylar sonucu meydana gelen talepler, muhalefetin olaylar üzerindeki etkisi, kitlesel eylemlerin özellikle gençlerden oluşması ve hükümetlerin olaylara yaklaşımı, benzerlik göstermektedir. 68 Olayları, 1960 öğrenci hareketleri ve Gezi Parkı Olayları'ndan farklı olarak hükümete bir muhalefet olarak gelişme göstermekten ziyade dünyada meydana gelen gelişmelerden etkilenmiştir. 1961 Anayasası ile özgürlüklerin o güne kadar 
hiç genişletilemediği kadar genişletilmesi, 1960 'da iktidarı indirdiğine inanan gençlerin bu yolla istediği her şeyi değiştirebileceğine dair daha güçlü bir inancın oluşması, 68 Olayları'nı tetiklemiştir.

Toplumsal hareketlerin siyasete katılım aracı olarak başarılı olabilmesi için gerek toplumsal hareketlerin muhataplarının, gerek muhatap olduğu iktidarın sağlam bir müzakere zemininde bir araya gelmesi gerekmektedir. Bireylerin kendilerini toplumsal ve siyasal alanın bir parçası olarak hissettiği, hem siyasal düzene uyumlu hem siyasal düzeni sorgulayıcı bir bilinçle hareket ettiği, iktidarın buna meşru bir zemin hazırladı $\breve{g} 1$ demokratik alanlar, toplumsal hareketlerin bir siyasi katılım aracı olarak varlığını koruyacaktır. Aynı zamanda toplumsal hareketlerin de iktidar olma amaciyla değil, siyasal alana etkide bulunma amacıyla bir araya gelmiş bireylerden oluşması demokrasinin işleyişini kolaylaştıracaktır. Ancak, Türkiye'de toplumsal hareketlerin demokrasinin işleyişi açısından gerekli bir mekanizma olduğu düşüncesinin dikkate alınmadığ görülmektedir. Bunun en önemli nedeni, toplumsal hareketlerin demokratik taleplerden çok, hükümet değişikliği talepleri ile gündeme gelmiş olmasıdır. Başbakan Menderes ve Erdoğan iktidarı döneminde meydana gelen toplumsal hareketler, seçimle işbaşına gelmiş iktidarı seçimle değiştireceğine inanmayanların kullandığı ve yönettiği bir araç olarak yorumlanmıştır. İktidar değişikliği talepleri ve buna yönelik eylemler, Türkiye'de meydana gelen toplumsal hareketlerin en temel özelliklerinden biri olmuştur. Siyasi tarih içerisinde toplumsal hareketlerin meydana getirdiği protesto eylemleri, zamanla şiddet eylemelerine dönüşmüş ve bir askeri müdahale ile sonuçlanmıştır. Bu nedenle, merkez sağ parti iktidarları, olayların çıkış nedeni ve talepleri üzerinde durmak yerine, olaylara karşı olumsuz bir tavır geliştirmiştir. Tüm bunlarla birlikte özellikle son dönemde meydana gelen Gezi Parkı Olayları'nda Erdoğan'ın gerek sanatçılar gerek eylemciler ile görüşmüş olması, toplumsal hareketleri ve talepleri tamamıyla reddettiği düşüncesini desteklememektedir. Erdoğan’ın attığı bu adım en azından toplumsal hareketlere karşı müzakere yolunu açmıştır.

Özetlemek gerekirse, Türkiye'de meydana gelen toplumsal hareketler, içerisinde geliştiği siyasi olaylar ve sonuçları nedeniyle, merkez sağ parti iktidarları tarafından çoğunlukla sisteme karşı bir başkaldırı ya da düzen bozucu eylemler olarak yorumlanmıştır. Ancak bu düşünce, toplumsal hareketlerin demokrasiye katkı sağlayan bir unsur olarak varlığını sürdürdüğü gerçeğini değiştirmez. İçerisinde geliştiği siyasi gelenek nedeniyle kimi zaman statik sistem, kimi zaman ordu, kimi zaman ise devletin kendisi tarafından kabul görmese dahi, Türkiye'de de zamanla muhalif hareketlerin de kurucu rol üstlenebildikleri belirli pratiklerle ortaya çıkacaktır.

\section{KAYNAKÇA}

Adalet Partisi, http://ap.org.tr/, Erişim Tarihi: 02.11.2019.

Ahmad, F. (1999), Modern Türkiye’nin Oluşumu, İstanbul: Kaynak Yayınları.

Akgün, Birol, (2006), Türkiye’de Merkez Sağ Siyaset Geleneği Ve Ak Parti, Muhafazakâr Düşünce, 3, 9-10.

Arslan, M. (2019), Süleyman Demirel, İstanbul: İletişim Yayınları.

Arslan, Zühtü, (2009), Türk Parlamento Tarihi TBMM- XI. DÖNEM (1957- 1960), I. CİLT, TBMM Kültür, Sanat Ve Yayın Kurulu Yayınları No:156.

Bora, Tanıl, (2017), Cereyanlar: Türkiye'de siyasi ideolojiler, İstanbul: İletişim Yayınları.

Caniklioğlu, M.Dikmen, (2007), Sivil Toplum ve Türkiye Demokrasisindeki İzdüşümleri, Ankara: Seçkin Yayıncılık.

Çaha, Ö. (2016), Sivil Toplum ve Devlet, Ankara: Orion Yayınları.

Çaha, Ömer, (1999), Liberal ve Sosyalist Ülkelerde Sivil Toplum, http://www.libertedownload.com/LD/arsiv/16/10-omer-cahaliberal-ve-sosyalist-ulkelerde-sivil-toplum.pdf, Erişim Tarihi: 10.11.2019.

Çaplı, B. DÜNDAR, C. 32. Gün Arşiv Belgeseli, https://www.youtube.com/watch?v=n0EBcIo4d4U, Erişim Tarihi: 05.11.2019.

Çavuşoğlu, H. (2009), “Türk Siyasi Hayatında Merkez Sağ Çizginin Tarihi, Fırat Üniversitesi Sosyal Bilimler Dergisi, 19, (2), 265-278.

Çolak, Y. (2017), Türkiye'de Kültürel İktidarın Kuruluşu 1923-1945, Ankara: Liberte Yayınları.

Çufalı, M. (2005), Çok Partili Hayata Geçiş Dönemi, Türkiye'de Siyasal Hayat, ed. S.BAKAN, İstanbul: Aktüel Yayınları.

Enerem, H.T. (2018), The Rıse And Declıne Of Center Rıght Partıes In Turkey, (Yayınlanmış Doktora Tezi), İstanbul: Yeditepe Üniversitesi.

Erdoğan, S. (2008), Anavatan Partisinin Siyasal Dönüşümü, (Yayınlanmış Doktora Tezi), Ankara: Ankara Üniversitesi Sosyal Bilimler Enstitüsü.

Erken, Baki, (2016), Türkiye’de Merkez Sağ İdeolojisini Siyasi Hareket Üzerinden Temellendirme Denemesi, CBÜ Sosyal Bilimler Dergisi, 14, (2).

32. Gün Arşiv, (2017), Demirkırat Belgeseli, https://www.youtube.com/watch?v=sBPfjeWbp9Q, Erişim Tarihi: 07.11.2019. 
Göka, E. \& Göral, F.S. , Güney, Ç., Bir Hayat İnsanı Olarak Türk Muhafazakarı ve Kaygan Siyasal Tercihi, Modern Türkiye’de Siyasi Düşünce, (Ed. Mehmet Ö.A. vd.), Cilt 5, İstanbul: İletişim Yayınları.

Gökmen, Ö. (2006) Tek Parti Dönemi Cumhuriyet Halk Partisi’nden Muhafazakâr Yönelimler, (Yay. Haz. Tanıl Bora, Murat Gültekingil ) Modern Türkiye'de Siyasi Düşünce, Muhafazakârlık, İstanbul: İletişim Yayınları.

Göktolga, O. (2005), Dünya'da Ve Türkiye'de 68 Hareketi Ve Sonuçları, Türkiye’de Siyasal Hayat, (Ed. A. Küçük vd.), İstanbul: Aktüel Yayınları ss.937-953.

Gümüş, Korhan, (2004), Yakın Tarihimizde STK Hareketinin Gelişimi Ve Kamu Sivil Toplum Kuruluşları İlişskisi, Bilgi Üniversitesi Sivil Toplum Kuruluşları ve Araştırma Birimi, Savunuculuk ve Politikaları Etkileme Konferans Yazıları, No:3.

Heper, M. (2011), Türkiye'nin Siyasal Hayatı, İstanbul: Doğan Kitap.

Heper, M. (2012), Türkiye'de Devlet Geleneği, Ankara: Doğu-Batı Yayınları.

https://www.youtube.com/watch?v=8bLpAwRQ4sY, Erişim Tarihi: 15.11.2019.

Kahraman, H.B. (2007), Türk Să̆ ve AKP, İstanbul: Agora Kitaplığı.

Kalaycıŏglu, E. (2013), Siyasal Katılmanın Anotomisi, Bilim Akademisi Derneği, Sabancı Üniversitesi, 34-179/148.

Köker, L. (2003), Liberal Muhafazakârlık ve Türkiye, Modern Türkiye'de Siyasi Düşünce, (Ed. Mehmet Ö. Alkan vd.), Cilt 5, İstanbul: İletişim Yayınları,

Mardin, Ş. (1995), Türkiye'de Toplum ve Siyaset, Der. Mümtaz’er Türköne/Tuncay Önder, İstanbul: İletişim Yayınları.

Mardin, Ş. (2018), Türkiye, İslam ve Sekülerizm, İstanbul: İletişim Yayınları,

Massıcard, É. (2016), Türkiye'den Avrupa'ya Alevi Hareketinin Siyasallaşması, İstanbul: İletişim Yayınları

Koca, M. (2018). 68 Öğrenci Olayları ve Üniversitelerde Politik Şiddet, Birey ve Toplum Sosyal Bilimler Dergisi, Bahar, 8, (15).

Mert, N. (2007), Merkez Să̆ın Kısa Tarihi, İstanbul: Selis Kitaplar.

Nişancı, Ş. (2003), Sivil İtaatsizlik, İstanbul: Okumuş Adam Yayıncılık.

Öngör, I. (2018), 2000’li Yıllarda Toplumsal Hareketler Ve Sivil Toplum Tartışmaları, ( Yayımlanmış Yüksek lisans Tezi), Ankara: Hacettepe Üniversitesi, Sosyal Bilimler Enstitüsü.

Özbudun, E. (2006), Türk Siyasal Hayatı, Eskişehir: Anadolu Üniversitesi Yayınları.

Özdemir, H. (2012), Demokrat Parti (DP) ile Adalet ve Kalkınma Partisi (AKP)'nin Karşılaştırmalı Tarihsel Analizi, Fırat Üniversitesi Sosyal Bilimler Dergisi, 22, (2), 188-209.

Özdemir, H. \&, Demirkanoğlu, Y. (2013), Türkiye’de Merkez Sağ Partilerin Kentsel Toprak Politikaları: Turgut Özal Dönemi Anavatan Partisi (ANAP) Örneği, Akademik Bakış Dergisi, 35.

Porta, D.Della, (2005), Deliberation in Movement: Why and How to Study Deliberative Democracy and Social Movements, Italy: Badia University, European University Institute, (9), 50016.

Recep Tayyip Erdoğan, Basın Toplantısı, https://www.youtube.com/watch?v=JgQti7AGzGg, Erişim Tarihi: 15.11.2019.

Sabah Gazetesi, Ana Muhalefet Kışkırtıyor, 03 Haziran 2013, s. 24. , Erişim Tarihi: 15.11.2019.

Sartorı, G. (1996), Demokrasi Teorisine Geri Dönüş, çev. Tunçer Karamustafaoğlu, Mehmet Turhan, Ankara: Yetkin Yayınları.

Sunar, İ. (2004), State, Society and Democracy in Turkey, İstanbul: Bahçeşehir University Publication.

Suveren, Y. (2016), Türkiye'de Muhafazakârlık Olgusunun Siyasal Algılanışı Üzerine: Bir Alan Çalışmasının Bulguları, Yakın Doğu Üniversitesi Íslam Tetkikleri Merkezi Dergisi, 2, (1), 107-137.

Szylıwıcz, S. (2017), Türkiye Kırsalında Siyasetin Dinamikleri, Ankara: Ankara Üniversitesi Türk İnkılâp Tarihi Enstitüsü , Atatürk Yolu Dergisi, 61, 493-510.

TBMM Kütüphanesi, file://C:/Users/Lenovo/Downloads/197600462_1969.pdf, Erişim Tarihi: 02.11.2019.

TBMM

Kütüphanesi, https://acikerisim.tbmm.gov.tr/xmlui/bitstream/handle/11543/643/199302257_1986.pdf?sequence=1\&isAllowed=y

The Guardian, https://www.theguardian.com/world/from-the-archive blog/2018/apr/06/paris-students-demonstrations-may1968, Erişim Tarihi: 10.11.2019.

Tilly, C. (2008), Toplumsal Hareketler, İstanbul: Babil Yayıncılık

Tuncel, G. (2011), Sivil Toplum ve Devlet, Malatya: BİLSAM Yayınları. 
Turku, E. (2018), Merkez Sağ Partilerde Liberalizm: DP-ANAP-Ak Parti İncelemesi, (Yayımlanmış Yüksek Lisans Tezi), Kırıkkale: Kırıkkale Üniversitesi Sosyal Bilimler Enstitüsü.

Zurcher, E.J. (2013), Modernleşen Türkiye'nin Tarihi, İstanbul: İletişim Yayınları. 